MR. CAIO ARTHUR SANTOS (Orcid ID : 0000-0001-7132-8167)

PROF. RICHARD W WHITE (Orcid ID : 0000-0002-5270-3985)

Article type : Original Article

\title{
The gabbro to amphibolite transition along a hydration front
}

Caio A. Santos ${ }^{1}$, Richard W. White ${ }^{2}$, Renato Moraes ${ }^{3}$ and Gergely A. J. Szabó ${ }^{3}$

1 - Post Graduation Program in Mineralogy and Petrology. Geosciences Institute, University of São Paulo, Rua do Lago 562, 05508-080, São Paulo, Brazil. caio.santos@usp.br

2 - School of Earth and Environmental Sciences, University of St. Andrews, KY16 9AL, UK.

3 - Department of Mineralogy and Geotectonics, Geosciences Institute, University of São Paulo, Rua do Lago 562, 05508-080, São Paulo, Brazil.

The gabbro to amphibolite transition

This article has been accepted for publication and undergone full peer review but has not been through the copyediting, typesetting, pagination and proofreading process, which may lead to differences between this version and the Version of Record. Please cite this article as doi: 10.1111/JMG.12582

This article is protected by copyright. All rights reserved 


\section{ABSTRACT}

In most metamorphic terrains the transition to the preserved mineral assemblage can be established to have occurred during progressive metamorphism through lower-grade facies involving fluid saturated conditions. However, in some circumstances metamorphism can occur in a non-progressive way as a distinct overprint of either igneous protoliths such as gabbro, or of earlier higher-grade metamorphic rocks such as granulites. In this contribution we use thermodynamic modelling, together with petrographic and mineral chemistry analysis, to study a suite of amphibolite facies metamafic rocks that were variably affected by metamorphism, with the objective of explaining the textures and mineral assemblages observed. The study samples form a continuum in terms of textural relationships and mineral compositions, but they can be divided into three main types: metagabbro, lineated metagabbro and amphibolite. Metagabbro samples preserve both relict igneous and metamorphic textures and a combination of igneous and metamorphic mineralogy. They preserve a variety of reaction textures, such as coronas of garnet around ilmenite, double coronas of low-Al (actinolitic) and high-Al (pargasitic) hornblende around clinopyroxene and limited degrees of recrystallization of igneous plagioclase. Lineated metagabbro samples preserve similar reaction textures as the metagabbro but show a strong lineation and have higher proportions of pargasitic hornblende and polygonal plagioclase combined with lower proportions of clinopyroxene, igneous plagioclase and actinolitic hornblende. Amphibolite samples are composed of pargasitic hornblende and polygonal plagioclase, presenting little igneous plagioclase and practically no garnet and clinopyroxene, and they preserve none of the reaction textures of the other two types. These samples are interpreted to be near chemically equilibrated on a hand sample scale, though with some mineral zoning preserved. $P-X_{\mathrm{H}_{2} \mathrm{O}}$ and $T-X_{\mathrm{H}_{2} \mathrm{O}}$ pseudosections show that the main mineral assemblage differences between the amphibolites and the other two types are primarily controlled by the amount of $\mathrm{H}_{2} \mathrm{O}$ that equilibrated with the rocks. While all rocks experienced an influx of fluid, only the 
amphibolites represent thermodynamically fluid-saturated conditions, the metagabbro and lineated metagabbro having equilibrated under $\mathrm{H}_{2} \mathrm{O}$ undersaturated conditions, allowing the presence of garnet. In parallel with the variation in fluid influx, the variation in microstructure appears to be the result of varying length scales of diffusion. The complex corona structures in the metagabbros are interpreted to reflect the pre-existing igneous texture and the apparent low mobility of Al during metamorphism. Here, igneous clinopyroxene is largely pseudomorphed by the actinolitic hornblende whereas the higher-Al pargasitic hornblende and garnet occur adjacent to plagioclase or replacing it. Zoning patterns in amphibole crystals in the amphibolite are similar to those in metagabbro samples, which is consistent with earlier stages of the evolution of the amphibolite actually being similar to those preserved in the metagabbro.

Keywords: gabbro, reaction textures, hydration

\section{INTRODUCTION}

Metamorphic rocks are usually investigated in terms of occurrence of systematic and progressive changes in the series of mineral assemblages developed in response to changes in temperature and pressure (e.g. Spear, 1993). However, that is not always the case: in nonprogressive metamorphism, when igneous rocks or $\mathrm{H}_{2} \mathrm{O}$-poor metamorphic rocks, are subjected to subsequent metamorphism, the transformation to typical metamorphic minerals and textures may be incomplete in the absence of sufficient fluid or deformation (e.g. Whitney \& McLelland, 1983; Rivers \& Mengel, 1988; Nicollet \& Goncalves, 2005; Schorn \& Diener, 2017; White \& Clarke, 1997).

Although several examples of non-progressive metamorphism have been studied, few examples of non-progressive, amphibolite facies metamafic rocks have been studied using modern modelling techniques and recent thermodynamic databases. In this work we use these tools, together with petrographic and mineral chemistry observations, to understand, in a semiquantitative way, the processes associated with hydration of a suite of mafic rocks in amphibolitefacies conditions.

\section{GEOLOGICAL SETTING}

The studied samples come from the Mantiqueira Complex, a unit that forms a belt at the southeastern margin of the São Francisco Craton, southeastern Brazil (Figure 1) and is interpreted 
to correspond to a portion of the São Francisco Craton reworked during the Neoproterozoic Brasiliano orogenic cycle (Brueckner, Cunningham, Alkmin \& Marshak, 2000; Figueiredo \& Teixeira, 1996; Noce, Pedrosa-Soares, Silva, Armstrong \& Piuzana, 2007; Cutts, Lana, Alkmim \& Peres, 2018). The Mantiqueira Complex is composed of intensely foliated migmatites and banded gneisses with granite to tonalite compositions, among which amphibolite lenses and boudins occur (Baltazar \& Raposo, 1993; Duarte, Valente, Heilbron \& Campos Neto, 2004). These rocks record crystallization ages from 2203 to 2041 Ma (Brueckner et al., 2000; Figueiredo \& Teixeira, 1996; Noce et al., 2007; Silva et al., 2002). Despite the fact that there is plenty of data on geochemical and geochronological characteristics of this unit (see review by Alkmim, Kuchenbecker, Reis \& Pedrosa-Soares, 2017), there is little information on metamorphism, with most authors generically citing amphibolite facies conditions. Cutts et al. (2018) studied a metapelite occurrence considered as part of the Mantiqueira Complex (east of the rocks studied here) and determined a temperature of $650{ }^{\circ} \mathrm{C}$ and pressures of 8-9 kbar.

The metamafic rocks studied here come from two very similar outcrops approximately 780 $\mathrm{m}$ distant from each other. Both are concentrations of loose, metre- to decimetre-sized, round shaped blocks, extending over areas of some tens of square meters. These conditions do not allow relationships between the different samples to be observed, and, likewise, the relationships between the mafic rocks and the host gneisses cannot be observed directly, as the nearest gneiss outcrop is $\approx 100 \mathrm{~m}$ distant. We infer that these blocks are parts of boudins in the gneisses based on their occurrence over restricted areas, their chemical similarity, the consistency of textures observed within 23 thin sections described and the comparison with other occurrences in the Mantiqueira Complex.

\section{WHOLE-ROCK CHEMISTRY}

Whole-rock chemical analyses of seven samples were obtained by X-ray fluorescence in the X-ray Fluorescence Laboratory of the NAP Geoanalítica - Geosciences Institute, University of São Paulo, Brazil, using a PANalytical AXIOS MAX spectrometer. Fused glass discs were prepared for analyses of major elements, while pressed powder pellets were prepared for analyses of minor elements. Both were prepared according to the procedures described by Mori, Reeves, Correia and Haukka (1999). $\mathrm{Fe}^{2+}$ contents were analyzed via wet chemical titration at the same laboratory. 
The samples analyzed include the three petrographic types described below, metagabbro, lineated metagabbro and amphibolite (Table 1). All the samples can, by their chemical composition, be classified as basalts of the tholeiitic series (Figure 2). Figure 2 and table 1 show that all compositions are very similar, with $49 \mathrm{wt} \% \mathrm{SiO}_{2}, 13 \mathrm{wt} \% \mathrm{Al}_{2} \mathrm{O}_{3}, 10 \mathrm{wt} \% \mathrm{CaO}$ and $\mathrm{Mg} /(\mathrm{Mg}$ $+\mathrm{Fe}^{2+}$ ) ratio of 0.5 .

\section{PETROGRAPHY}

The petrographic study was carried out on 23 samples and correspondent thin sections, from which the samples analyzed for whole-rock composition and mineral chemistry were selected. In the following description dark green amphiboles will be referred to as pargasitic hornblende, while colorless to pale green amphiboles will be referred to as actinolitic hornblende. This is because each set, while visually distinct, exhibits a range of compositions that would cover several amphibole types in most classification schemes (e.g. Hawthorne et al. 2012). Nomenclature details are presented in section 5. In the figures, as in the phase diagrams, mineral abbreviations follow Holland \& Powell (2011). In figures where the distinction can be made, tabular plagioclase (interpreted as igneous) is labeled pll, while fine-grained, polygonal plagioclase is labeled $p l 2$. Likewise, pargasitic hornblende is labeled $h b l$, while actinolitic hornblende is labeled $h b 2$.

The study samples form a continuum in terms of textural and mineralogical variation, but they can be subdivided into three basic types: metagabbro, lineated metagabbro, and amphibolite. These types will be described below.

\subsection{Metagabbro}

Metagabbro samples (PNF 01A, 02-IV-10A, 05-III-20, 07-II-08, 09-VIII-8A) are mediumgrained and their crystals display no preferred orientation. They present hypidiomorphic granular texture (Figure 3a). They are composed of 30-35\% plagioclase, 35-40\% pargasitic hornblende, $10-15 \%$ actinolitic hornblende, 10-15\% clinopyroxene and accessory amounts of garnet, biotite, ilmenite and quartz. Plagioclase grains of inferred igneous origin are tabular, up to $2 \mathrm{~mm}$ long, and their rims are usually corroded. Some samples present a minor second generation of plagioclase, formed by smaller $(0.02 \mathrm{~mm})$, polygonal crystals, which occur at the rims of and along fractures in 
the igneous tabular crystals (Figure 3b). Clinopyroxene crystals are subhedral, up to $0.5 \mathrm{~mm}$ long, and also present corroded rims (Figures $3 a, b, 4 c-d$ ).

Hornblende occurs as pale green to colorless crystals (actinolitic hornblende) and as dark green crystals (pargasitic hornblende). Both occur as fine-grained anhedral crystals, but pargasitic hornblende is somewhat coarser-grained than actinolitic hornblende. Additionally, actinolitic hornblende rarely displays cummingtonite exsolution lamellae (Figure 3c). Ilmenite is generally subhedral, and, in rare examples, displays hematite intergrowths, which in turn display thinner ilmenite intergrowths. By contrast, ilmenite crystals associated with garnet (see below) present very irregular shape (see Figures 3d, 4e-f). Garnet crystals are irregular shaped, but some present rectilinear crystal faces, especially in contacts with plagioclase. Biotite is brown colored, fine grained and subhedral.

The metagabbro samples present a wide variety of reaction textures. The most common of these is actinolitic hornblende that partially to totally pseudomorphs igneous clinopyroxene, and is, in turn, mantled by pargasitic hornblende (Figures 4a-d). In detail, it can be noted that the replacement of clinopyroxene by actinolitic hornblende commonly starts along micrometer-scale planes within the clinopyroxene (Figure 3e) and that even the innermost parts of clinopyroxene crystals display some degree of replacement. In cases where replacement of clinopyroxene is complete or nearly complete the actinolitic hornblende aggregates can include few micrometric, round quartz crystals. Although uncommon, pargasitic hornblende is sometimes in direct contact with clinopyroxene.

Another common reaction texture consists of ilmenite crystals partially or totally mantled by garnet (Figures 4e-f). Additionally, garnet also occurs as small isolated euhedral crystals without an apparent ilmenite core and along contacts between plagioclase and pargasitic hornblende. Garnet in mantles around ilmenite commonly presents biotite and hornblende inclusions (Figures 3d, 4e-f). Some subhedral ilmenite crystals are mantled by hornblende or by biotite, without garnet (Figures $4 \mathrm{a}-\mathrm{d}$ ). In several cases, ilmenite is partially mantled by garnet and partially mantled by hornblende, and these hornblende mantles link with mantle around porphyroblasts after clinopyroxene (Figure 3d); sometimes the net effect of such combination of textures is that pargasitic hornblende seems to form a matrix around the other phases. Moreover, there are no direct contacts between either of ilmenite, plagioclase and clinopyroxene. Another 
noteworthy textural feature is that fine-grained pargasitic hornblende crystals are sometimes present at the interstices between tabular plagioclase crystals (Figure 3f).

\subsection{Lineated metagabbro}

Lineated metagabbro samples (07-III-7C, 09-XII-8B) display a pervasive lineation, which is defined mainly by mineral aggregates, rather than crystals of elongate shape (although some crystals are elongate, see below). In thin section it can be seen that the lineation is somewhat anastomosed (Figure 5a). Due to outcrop conditions, as described earlier, the orientation of the lineation cannot be measured.

The aggregates mentioned above are 0.2 to $1.0 \mathrm{~mm}$ thick, and are of two types, which occur intercalated: one type is composed of tabular plagioclase + polygonal plagioclase \pm finegrained pargasitic hornblende, and the other type is composed of pargasitic hornblende + actinolitic hornblende \pm clinopyroxene \pm ilmenite \pm garnet \pm quartz (Figure 5b). Tabular plagioclase crystals are commonly orientated parallel to this lineation; garnet commonly takes unusual elongate shapes, which are also parallel to the lineation (Figure 5c), while clinopyroxene crystals are wrapped by the lineation (Figure 5d). Other minerals are not orientated and display the same habits as described for the metagabbros. In these samples clinopyroxene (2-5\%), actinolitic hornblende $(5-10 \%)$ and tabular plagioclase $(15-20 \%)$ are modally less common than in the metagabbro, while the proportions of pargasitic hornblende $(\approx 50 \%)$ and fine-grained polygonal plagioclase (15-20\%) are higher. Some igneous plagioclase remnant crystals are surrounded by polygonal metamorphic plagioclase aggregates (Figures 6a-b). The modal amount of each of garnet, biotite and ilmenite shows no significant variation relative to what is observed in the metagabbro samples.

In lineated metagabbro samples actinolitic hornblende occurs as pseudomorphs after clinopyroxene, which are, in turn, mantled by pargasitic hornblende as in the metagabbro, and the textural similarity includes the replacement of clinopyroxene along micrometer-scale planes. The main difference, relative to the metagabbro samples is that, in cases where the replacement of clinopyroxene is complete or nearly complete, hornblende forms elongated aggregates, instead of pseudomorphs (Figures 5a, b). 
Garnet commonly forms mantles around ilmenite, with the only difference from the metagabbro being that in this case textures are commonly elongated (Figures 5c, 6c-d). Garnet commonly displays intergrowths or small inclusions of hornblende and biotite. Hornblende and biotite in places mantle ilmenite, but this less common than in the metagabbro. As was described for the metagabbro samples, the different textures merge into one another.

\subsection{Amphibolite}

Amphibolite samples (PNF 01B, 06-IX-54, 06-X-66) are fine- to medium grained and display variable intensity of foliation and lineation, which is defined by intercalated submilimetric aggregates of pargasitic hornblende and metamorphic plagioclase (Figure 7a). They are composed of $\approx 60 \%$ pargasitic hornblende and $\approx 30 \%$ fine-grained polygonal plagioclase. Both plagioclase and pargasitic hornblende occur as fine-grained polygonal crystals (Figures 7b, c), similar to their metagabbro equivalents, although hornblende can rarely occur as larger crystals, possibly pseudomorphs after clinopyroxene. These samples bear minor proportions of tabular igneous plagioclase, actinolitic hornblende and ilmenite, almost no garnet or clinopyroxene, and contain accessory proportions of quartz, titanite, and biotite, all of them occurring amid the hornblende aggregates; quartz is similar in mode of occurrence to its metagabbro and lineated metagabbro counterparts, biotite is subhedral, and displays the same brown color as biotite in the metagabbro and lineated metagabbro, while titanite is anhedral. Some samples bear scapolite as an accessory mineral, which is anhedral and occurs associated with the plagioclase aggregates. In contrast to metagabbro and lineated metagabbro, these samples preserve no reaction textures, except for titanite mantles around ilmenite. The rare garnet crystals are euhedral.

\section{MINERAL CHEMISTRY}

Mineral chemistry data, along with back-scattered electron images and WDS compositional images, were obtained with a JEOL JXA-FE-8530 equipment at the Electron Microprobe Laboratory of the NAP Geoanalítica - Geosciences Institute/University of São Paulo; with a JEOL JXA-8230 Superprobe at the Electron Microprobe Laboratory of the Institute of Geosciences and Exact Sciences/São Paulo State University (Rio Claro) and at the Electron Microprobe Laboratory of the Institute of Geosciences/University of Mainz using a JEOL JXA8900. Analyses were carried on using $15 \mathrm{kV}$ acceleration voltage and $20 \mathrm{nA}$ probe current, with probe diameter of $5 \mu \mathrm{m}$ for all minerals except plagioclase, for which $10 \mu \mathrm{m}$ probe diameter was 
used. Synthetic and natural mineral standards were employed for element calibration. The dataset is available as supporting information (Tables S1-S6).

For ilmenite, hematite, garnet and clinopyroxene the $\mathrm{Fe}^{3+}$ content was calculated using the method described by Droop (1987). For amphiboles the $\mathrm{Fe}^{3+}$ content was calculated using the Schumacher method (described in Leake et al., 1997).

Given their similarities, metagabbro and lineated metagabbro samples will be treated together in the following description, while amphibolite samples will be discussed separately.

\subsection{Hornblende}

Hornblende is the main phase of the studied rocks. Due to the large number of analyses performed, the diagrams of Figure 8 only show data from samples 05-III-20 (a metagabbro, Figures $8 \mathrm{a}, 8 \mathrm{c} 8 \mathrm{e}$ ) and 09-XII-8B (a lineated metagabbro, Figures 8b, 8d, 8f), but there are no important differences between the samples. Diagrams showing the chemical composition of amphibole from the remaining samples are available as supporting information (Figure S1).

In the metagabbro and lineated metagabbro samples hornblende can be divided into two groups: the near-colorless crystals that occur as pseudomorphs after clinopyroxene (referred to as actinolitic hornblende) and the dark-colored crystals that occur in different textural contexts (referred to as pargasitic hornblende). These two groups span several fields of the classification diagrams of Hawthorne et al. (2012), and in some cases analyses from these two different groups would receive the same mineral name. So, for the sake of clarity and simplicity we use, for the groups defined in this work, descriptive names that are not used in the classification scheme of Hawthorne et al. (2012), that reflect the textural setting and appearance. The complete table of analyses, which is available as supporting information, contains a row with the formal mineral name for each analysis (Table S1).

Actinolitic hornblende has VIAl contents between 0.1 and 0.4 atoms per formula unit (apfu), ${ }^{\mathrm{IV}} \mathrm{Al}$ between 0.3 and $1.0 \mathrm{apfu},{ }^{\mathrm{A}}(\mathrm{Na}+\mathrm{K})$ between 0.04 and 0.4 apfu and $\mathrm{Mg} /\left(\mathrm{Mg}+\mathrm{Fe}^{2+}\right)$ between 0.6 and 0.75 (Figure 8). Some actinolitic hornblende crystals contain cummingtonite exsolution lamellae with low ${ }^{\mathrm{VI}} \mathrm{Al}$, between 0.0 and $0.2 \mathrm{apfu},{ }^{\mathrm{IV}} \mathrm{Al}$ between 0.2 and $0.5 \mathrm{apfu}, \mathrm{Ca}$ between 0.4 and $0.9 ; \mathrm{Mg} /\left(\mathrm{Mg}+\mathrm{Fe}^{2+}\right)$ between 0.5 and 0.6 and ${ }^{\mathrm{A}}(\mathrm{Na}+\mathrm{K})$ between 0.04 and 0.1 . 
The composition of pargasitic hornblende crystals is largely independent of the textural context: ${ }^{\mathrm{VI}} \mathrm{Al}$ varies between 0.4 and $0.8 \mathrm{apfu},{ }^{\mathrm{IV}} \mathrm{Al}$ between 1.2 and $2.1 \mathrm{apfu},{ }^{\mathrm{A}}(\mathrm{Na}+\mathrm{K})$ between 0.4 and 0.8 apfu, and $\mathrm{Mg} /\left(\mathrm{Mg}+\mathrm{Fe}^{2+}\right)$ between 0.4 and 0.6. In detail, it can be noted that hornblende in interstices between plagioclase crystals has lower Ti than hornblende that mantles clinopyroxene pseudomorphs, which, in turn, has lower Ti than hornblende associated with garnet or ilmenite.

The compositional transition from the pseudomorphs to the mantles is abrupt, and the mantles themselves are compositionally zoned, with "more pargasitic" compositions towards the contact with plagioclase. In the lineated metagabbro it can be noted that individual hornblende crystals are sometimes zoned, usually displaying actinolitic cores and pargasitic rims, but in rare cases displaying the reverse (Figure 9c). Furthermore, while in the undeformed samples the distribution of the pargasitic hornblende crystals closely follows the contacts between the hornblende aggregates and plagioclase, this pattern is less pronounced in the lineated ones.

In amphibolite samples, hornblende occurs both as polygonal aggregates and as rare pseudomorphs after clinopyroxene. Some polygonal crystals preserve compositional zoning, which are of two types: actinolitic cores with pargasitic rims and pargasitic cores with more actinolitic rims. The first type of zoning involves an abrupt compositional jump and has a greater overall compositional range, while the second involves more gradual and continuous compositional variation over a smaller range (Figure 7c). The actinolitic cores have VIAl between 0.05 and $0.16 \mathrm{apfu},{ }^{\mathrm{IV}} \mathrm{Al}$ between 0.8 and $1.0 \mathrm{apfu},{ }^{\mathrm{A}}(\mathrm{Na}+\mathrm{K})$ between 0.1 and 0.2 apfu and $\mathrm{Mg} /\left(\mathrm{Mg}+\mathrm{Fe}^{2+}\right) \approx 0.75$. The other hornblende types have very similar compositions, with ${ }^{\mathrm{VI}} \mathrm{Al}$ between 0.4 and 0.6 apfu, ${ }^{I V} \mathrm{Al}$ between 1.4 and 1.8 apfu, ${ }^{\mathrm{A}}(\mathrm{Na}+\mathrm{K})$ between 0.35 and 0.45 apfu and $\mathrm{Mg} /\left(\mathrm{Mg}+\mathrm{Fe}^{2+}\right) \approx 0.6$, with the pargasitic cores displaying just slightly higher ${ }^{\mathrm{VI}} \mathrm{Al},{ }^{\mathrm{IV}} \mathrm{Al}$ and ${ }^{\mathrm{A}}(\mathrm{Na}+\mathrm{K})($ Figure 10).

\subsection{Plagioclase}

Tabular plagioclase in metagabbro is zoned: cores compositions are mostly between $\mathrm{An}_{50}$ and $\mathrm{An}_{68}$, while rims have compositions mostly between $\mathrm{An}_{20}$ and $\mathrm{An}_{40}$ (Figure 11a). This zoning is more pronounced near the rims. Recrystallized plagioclase in the metagabbro samples displays more sodic compositions, mostly between $\mathrm{An}_{20}$ and $\mathrm{An}_{40}$ (Figure 11b). There is no compositional variation between analyses from different samples. Polygonal plagioclase from amphibolite 
display anorthite contents mostly between $33 \%$ and $45 \%$. Rare relict tabular grains display a chemical zoning similar to what is observed in the metagabbro samples, from $\mathrm{An}_{62}$ to $\mathrm{An}_{38}$ (Figure 11c).

\subsection{Clinopyroxene}

Clinopyroxene is usually diopside, with wollastonite contents near $45 \%$, but some analyses show wollastonite contents as low as $30 \% . \mathrm{Mg} /\left(\mathrm{Mg}+\mathrm{Fe}^{2+}\right)$ is always near 0.7 (Figure 12a), and $\mathrm{Na}, \mathrm{Al}$ and $\mathrm{Ti}$ contents are always low, less than $0.15,0.3$ and $0.1 \mathrm{apfu}$, respectively. There is no noteworthy chemical zoning within grains, and there are no compositional differences between crystals from different samples.

\subsection{Garnet}

Garnet compositions show no consistent variation with textural setting, with the exception of compositional zoning towards plagioclase grain boundaries. Almandine $(60-65 \%)$ and grossular (15-20\%) are the dominant end-members, with pyrope accounting for $9-11 \%$, and spessartine varying between 2.5 and 7\% (Figure 12b). Chemical variation within individual garnet crystals is a function of proximity to plagioclase, with $\mathrm{Ca}$ content being higher near plagioclase (Figure 13). Thus, garnet coronas between ilmenite and plagioclase exhibit a monotonic zoning of increasing grossular content toward plagioclase, coupled with decrease in the remaining components.

\subsection{Biotite}

Biotite crystals in metagabbro and lineated metagabbro samples have a uniform composition, with no significant differences between different samples or textural contexts. Total $\mathrm{Al}$ varies between 1.3 and $1.4 \mathrm{apfu}$, Si content is $2.7 \mathrm{apfu}$ and $\mathrm{Mg} /\left(\mathrm{Mg}+\mathrm{Fe}^{2+}\right) \approx 0.5$. Biotite crystals from amphibolite display very similar compositions, with total Al between 1.4 and 1.5 apfu and the same $\mathrm{Mg} /\left(\mathrm{Mg}+\mathrm{Fe}^{2+}\right)$ ratio and $\mathrm{Si}$ content (Figure 14).

\subsection{Ilmenite}

Ilmenite in the studied rocks has almost ideal $\mathrm{FeTiO}_{3}$ formula. Some crystals, however, present exsolution lamellae, whose compositions are intermediate between hematite and ilmenite. 
The interpretation of this feature is that igneous ilmenite composition was also intermediate between ilmenite and hematite.

\section{PHASE DIAGRAM MODELING}

\subsection{On the use of thermodynamic modelling}

In the case studied here, thermodynamic modelling, in particular pseudosections, has some limitations. The rocks that present reaction textures obviously did not attained equilibrium at thinsection scale, and therefore are technically not suitable for modelling using pseudosections based on measured bulk compositions. On the other hand, other modelling approaches, such as the use of $\mu-\mu$ diagrams, are hindered by the simplifications that would have to be made in order to render the $\mu$ relationships into a two or three dimensional diagram (see White, Powell \& Baldwin; 2008; Schorn \& Diener, 2017), and by uncertainty on the conditions of formation (see below). Moreover, as discussed by Forshaw, Waters, Pattison, Palin and Gopon, (2019) and Santos, Moraes and Szabó (2019), imperfections in the current version of the activity composition models may result in discrepancies in the predicted stabilities and compositions of amphibole and clinopyroxene, which is partially reflected in the calculations performed here. Nonetheless, thermodynamic calculations can still be used in a semi-quantitative or qualitative way, and will be used and discussed in the light of these limitations.

\subsection{Modelling conditions}

$P-T, \quad P-X_{\mathrm{H}_{2} \mathrm{O}}$ and $T-X_{\mathrm{H}_{2} \mathrm{O}}$ pseudosections were constructed using version 3.45 of THERMOCALC (Powell \& Holland, 1988) and dataset ds62 (Holland \& Powell, 2011, created February $6^{\text {th }}, 2012$ ). Isopleths were calculated using the software TCInvestigator (Pearce, White and Gazley, 2015). The activity-composition models used are those presented by White, Powell, Holland, Johnson and Green (2014) and Green et al. (2016) and references therein. Green et al. (2016) present two different clinopyroxene activity-composition models: the "omphacite model" takes into account order-disorder in M1 and M2 sites; and the "augite model" does not consider this order-disorder parameter, but allows $\mathrm{Al}$ in the $\mathrm{T}$ site and $\mathrm{Fe}^{2+}$ and $\mathrm{Mg}$ in the $\mathrm{M} 2$ site. The two models produce similar results in low- $T$ greenschist and amphibolite facies conditions (Green et $a l ., 2016)$. The "omphacite model" is used in all calculations performed here. 
Three compositions were used in the phase diagram calculations: the compositions of samples PNF 01B (an amphibolite) and 02 IV 10A (a metagabbro) and a modified version of 02 IV 10A, which will therefore be referred to as "02 IV 10M". This artificial composition, an attempt at a composition closer to the actual equilibration volume at the metagabbro sample, was constructed by the removal of clinopyroxene and igneous plagioclase, using their modes and the average composition of these phases, from all metagabbro samples from which mineral chemistry data is available.

In order to define the $\mathrm{Fe}^{3+} /\left(\mathrm{Fe}^{3+}+\mathrm{Fe}^{2+}\right)$ ratio (therefore denoted as $\left.X_{\mathrm{Fe}^{3+}}\right)$ to be used in the calculations, $\mathrm{Fe}^{2+}$ contents were determined. These results are likely to provide an overestimation of $X_{\mathrm{Fe}^{3+}}$ to some unknown degree (see Diener \& Powell, 2010), so the effects of different choices of $X_{\mathrm{Fe}^{3+}}$ ratio were evaluated using a series of $P-T$ pseudosections for our most well-equilibrated sample (PNF 01B), calculated with four different values of $X_{\mathrm{Fe}^{3+}}$.

We constructed $P-T$ pseudosections for the range $425-700{ }^{\circ} \mathrm{C}$ and $2-12 \mathrm{kbar}$, using two assumptions regarding $\mathrm{H}_{2} \mathrm{O}$ : as an excess phase and at the fixed value of $3.5 \mathrm{~mol} \%$. For the diagrams constructed with $\mathrm{H}_{2} \mathrm{O}$ in excess, melt is predicted to occur in the higher $T$ part of the covered $P-T$ range, but no melt-bearing equilibria were calculated, as they are not relevant to our discussion, and, moreover, the assumption of $\mathrm{H}_{2} \mathrm{O}$ to be in excess would lead to unrealistic melt proportions (Droop \& Brodie, 2012; Weinberg \& Hasalová, 2015; White, Powell \& Holland, 2001). In the case of the diagrams calculated for a fixed $\mathrm{H}_{2} \mathrm{O}$ proportion, omphacite is predicted to be stable at relatively low pressures, but no omphacite-bearing equilibria were calculated, since they are not relevant to the present discussion.

The $P-X_{\mathrm{H}_{2} \mathrm{O}}$ and $T-X_{\mathrm{H}_{2} \mathrm{O}}$ pseudosections were calculated from $\mathrm{H}_{2} \mathrm{O}$ contents of $10 \mathrm{~mol} \%$ down to the disappearance of hornblende, which typically occurs at $\mathrm{H}_{2} \mathrm{O}$ contents of $\approx 0.6 \mathrm{~mol} \%$. No amphibole-absent equilibria were calculated. $10 \mathrm{~mol} \% \mathrm{H}_{2} \mathrm{O}$ was enough to fluid-saturate the rock at lowest conditions in all but one pseudosection. Following the procedure adopted for the $P$ $T$ pseudosections, no melt-bearing equilibria were calculated.

\subsection{Results}

\subsubsection{Sample PNF 01B (amphibolite)}


$P-T$ pseudosections for the composition of PNF 01B were calculated using $X_{\mathrm{Fe}^{3+}}$ values of $\approx 0,0.09,0.15$ and 0.18 (Figures 15,16 ). The last $X_{\mathrm{Fe}^{3+}}$ value was obtained using the analyzed $\mathrm{Fe}^{2+}$ content (taken here to correspond to the maximum $\mathrm{Fe}^{3+}$ content), and the intermediate values were obtained by multiplying this maximum value by 0.5 and 0.8 . All pseudosections show typical sequences of mineral assemblages, with greenschist facies conditions characterized by actinolite + epidote + albite + chlorite + titanite + quartz + biotite. As temperature increases, hornblende and plagioclase are predicted to be introduced, while albite, actinolite and epidote are predicted to react out. Diopside is calculated to be stable at $T>\approx 500{ }^{\circ} \mathrm{C}$ and variable pressure. Glaucophanebearing assemblages are predicted to occur at pressures higher than $\approx 8.5 \mathrm{kbar}$ and temperatures lower than $\approx 480{ }^{\circ} \mathrm{C}$, while omphacite is predicted to appear at pressures higher than $\approx 11 \mathrm{kbar}$ at $425{ }^{\circ} \mathrm{C}$. Neither garnet nor rutile is calculated to be stable in the covered $P-T$ range.

The main difference between the diagrams is that decreasing $X_{\mathrm{Fe}}{ }^{3+}$ produces a general shift of phase boundaries to higher pressures, as already shown in previous works (e.g. Diener \& Powell, 2010; Santos et al., 2019). The observed mineral assemblage, i.e., hornblende + plagioclase + titanite + quartz + biotite, is calculated to be stable within the covered $P-T$ range in all diagrams, at temperatures between $\approx 550{ }^{\circ} \mathrm{C}$ and $\approx 650{ }^{\circ} \mathrm{C}$. The field of this assemblage is limited towards higher pressures by the diopside-in boundary, which, as mentioned above, shifts to higher pressures with decreasing $X_{\mathrm{Fe}^{3+}}$.

Isopleths of hornblende $X_{\mathrm{Al}}^{\mathrm{M} 2}$ and $(\mathrm{Na}+\mathrm{K})^{\mathrm{A}}$ are shown in Figures 15 and 16, while isopleths of hornblende $\mathrm{Mg} /\left(\mathrm{Mg}+\mathrm{Fe}^{2+}\right)$, hornblende $X_{\mathrm{Fe}^{3+}}{ }^{\mathrm{M} 2}$, diopside mode and plagioclase anorthite content are shown as supporting information (Figures S2-S5). As observed for field boundaries, the calculated isopleths shift to higher pressures as $X_{\mathrm{Fe}^{3+}}$ decreases, but the range of values observed in any given field do not vary much between the diagrams, with the obvious exception of hornblende $X_{\mathrm{Fe}^{3+}}{ }^{\mathrm{M} 2}$. In general, the observed hornblende $X_{\mathrm{Al}}{ }^{\mathrm{M} 2}(0.17-0.24)$ and $(\mathrm{Na}+$ $\mathrm{K})^{\mathrm{A}}(0.33-0.43)$ values are predicted to overlap at relatively low diopside modes (down to $<2 \%$ ), but they do not overlap with analyzed anorthite content in plagioclase $(0.37-0.48)$, which would occur at pressures 1-2 kbar higher. Predicted hornblende $\mathrm{Mg} /\left(\mathrm{Mg}+\mathrm{Fe}^{2+}\right)$ is fairly constant across the covered $P-T$ range in all diagrams, being always slightly lower than analyzed values $(\approx 0.6)$. Predicted $\mathrm{Fe}^{3+}$ contents in hornblende are, across the modelled $P$ - $T$ range, always smaller than the values estimated from stoichiometry $\left(X_{\mathrm{Fe}^{3+}}{ }^{\mathrm{M} 2}=0.26-0.37\right)$, even when minimum $\mathrm{Fe}^{3+}$ estimates 
are considered $\left(X_{\mathrm{Fe}^{3+}}{ }^{3 \mathrm{M} 2}=0.23-0.32\right)$. Obviously, the closest predicted values are obtained with the highest bulk $X_{\mathrm{Fe}^{3+}}$. Overall, none of the $X_{\mathrm{Fe}^{3+}}$ values used yields a perfect agreement between calculated and observed mineral assemblages and hornblende and plagioclase compositions, which likely relates to one or more of the factors cited in section 6.1. Moreover, no choice of $X_{\mathrm{Fe}^{3+}}$ yields clearly better results, so, for the calculations for sample 02 IV $10 \mathrm{~A}$, we arbitrarily chose to multiply the measured $X_{\mathrm{Fe}}{ }^{3+}$ by 0.8 (as in Figure 15b) to account for a small degree of surface oxidation.

\subsubsection{Sample 02 IV 10A (metagabbro) and composition "02 IV 10M"}

Sample 02 IV 10A is chemically very similar to PNF 01B (as are all analyzed samples), and, accordingly, the pseudosection calculated for its composition displays roughly the same sequence of mineral assemblages (Figure 17a), with the assemblage hornblende + plagioclase + titanite + quartz + biotite calculated to be stable between $\approx 500$ and $\approx 650{ }^{\circ} \mathrm{C}$, at pressures below 4 kbar, as the stability field of this assemblage is limited, towards higher pressure, by the appearance of diopside. As is the case for the composition of sample PNF 01B, garnet is not predicted to be stable in the covered $P-T$ range.

Figure $17 \mathrm{~b}$ shows the $P-T$ pseudosection calculated for composition 02 IV 10M. Although the predicted assemblage at greenschist conditions is the same as in the previous diagrams, the assemblages predicted to be stable at higher temperatures are different, with epidote being restricted to $T<\approx 500{ }^{\circ} \mathrm{C}$, chlorite calculated stability field going up to $525{ }^{\circ} \mathrm{C}$, plagioclase being restricted to $P<\approx 4.5 \mathrm{kbar}$ and diopside predicted to be stable only at $T>620-660{ }^{\circ} \mathrm{C}$. The overall result is that the assemblage hornblende + titanite + ilmenite + quartz + biotite is predicted to be stable over a large $P-T$ field. Garnet-bearing assemblages are calculated to be stable at $T>\approx 525$ ${ }^{\circ} \mathrm{C}$ and $P>\approx 10 \mathrm{kbar}$.

$T-X_{\mathrm{H}_{2} \mathrm{O}}$, and $\mathrm{P}-\mathrm{X}_{\mathrm{H}_{2} \mathrm{O}}$ pseudosections were calculated for the composition of sample $02 \mathrm{IV}$ 10A and for composition 02 IV 10M (Figures 18 and 19), while diagrams calculated for sample PNF 01B, using all the $X_{\mathrm{Fe}^{3+}}$ values used for Figures 15 and 16, are available as supporting information (Figures S6-S9). These diagrams present the transition from typically metamorphic mineral assemblages, at high $\mathrm{H}_{2} \mathrm{O}$ contents, to igneous-like ones, at low $\mathrm{H}_{2} \mathrm{O}$ contents, even at low temperatures. In these pseudosections, hydrated minerals other than hornblende and biotite 
become unstable shortly after the system becomes undersaturated in $\mathrm{H}_{2} \mathrm{O}$, which occurs below $\mathrm{H}_{2} \mathrm{O}$ contents of 5-6 mol\%, depending mainly on temperature. In all pseudosections diopside is predicted to become stable at $\mathrm{H}_{2} \mathrm{O}$ contents just below the fluid absent boundary. Ilmenite substitutes for titanite as the Ti-bearing phase at 4.5-3.0 mol\% $\mathrm{H}_{2} \mathrm{O}$, lower $\mathrm{H}_{2} \mathrm{O}$ values being associated to lower temperatures and higher pressures. Rutile is predicted to be the Ti-bearing phase at $P>7-8$ kbar and $\mathrm{H}_{2} \mathrm{O}$ contents of less than 3-4 mol \%.

Garnet is calculated to be stable from $\mathrm{H}_{2} \mathrm{O}$ contents of $\approx 6.0 \mathrm{~mol} \%$, while orthopyroxene is generally predicted to be stable at $\mathrm{H}_{2} \mathrm{O}$ contents minor than $3.5-5.0 \%$. It can be noted that there is an interplay between garnet and orthopyroxene, with the first being predicted to be stable at lower temperatures and higher pressures and the last being the opposite, with an intermediary zone of the $P_{-}$or $T-X_{H_{2} O}$ space where the two phases are predicted to coexist.

Figures 18 and 19 also show isopleths of hornblende $X_{\mathrm{Al}}{ }^{\mathrm{M} 2}$ and $(\mathrm{Na}+\mathrm{K})^{\mathrm{A}}$ and garnet $\mathrm{Mg} /\left(\mathrm{Mg}+\mathrm{Fe}^{2+}\right)$, with additional isopleths available as supporting information (Figures S10-S11). Hornblende $(\mathrm{Na}+\mathrm{K})^{\mathrm{A}}$ and $\mathrm{Mg} /\left(\mathrm{Mg}+\mathrm{Fe}^{2+}\right)$ are calculated to increase with $\mathrm{H}_{2} \mathrm{O}$ decrease, while $X_{\mathrm{Al}}^{\mathrm{M} 2}$ shows are more strong dependence relative to temperature and pressure, except for the $P$ $X_{\mathrm{H}_{2} \mathrm{O}}$ pseudosection calculated for the composition $02 \mathrm{IV} 10 \mathrm{M}$, where it is predicted to increase with decreasing $\mathrm{H}_{2} \mathrm{O}$. Plagioclase anorthite content and garnet $\mathrm{Mg} /\left(\mathrm{Mg}+\mathrm{Fe}^{2+}\right)$ are also predicted to increase with decreasing $\mathrm{H}_{2} \mathrm{O}$, while, for the pressure and temperature chosen, $\mathrm{Ca}$ content in garnet display opposite tendencies in $T-X_{\mathrm{H}_{2} \mathrm{O}}$, and $\mathrm{P}-\mathrm{X}_{\mathrm{H}_{2} \mathrm{O}}$ pseudosections, for both compositions.

$P-T$ pseudosections were constructed for the composition of sample 02 IV $10 \mathrm{~A}$ and for composition $02 \mathrm{IV} 10 \mathrm{M}$ (Figure 20), assuming a fixed $\mathrm{H}_{2} \mathrm{O}$ content of $3.5 \mathrm{~mol} \%$. A pseudosection calculated for the composition of sample PNF 01B, under the same assumption, is available as supporting information (Figure S12), and, as was the case for Figures 18 and 19, a selection of isopleths is shown in Figure 20, and additional variables are available as supporting information (Figure S13). The $\mathrm{H}_{2} \mathrm{O}$ content of $3.5 \mathrm{~mol} \%$ was chosen in order to depict garnet bearing equilibria.

In both diagrams hornblende and diopside are predicted to be stable along all the covered $P-T$ range, together with quartz and biotite. The interplay between garnet and orthopyroxene is shown to be related mainly to pressure, with both pseudosections showing orthopyroxene stable at low pressures and garnet stable at pressures higher than 3-5 kbar, with an intermediate field where 
both are predicted to be stable, which is narrow for 02 IV $10 \mathrm{~A}$ and much broader for 02 IV $10 \mathrm{M}$. The pseudosection for the composition of sample 02 IV 10A predicts albite- and titanite-bearing assemblages to be stable at low temperatures, with plagioclase and ilmenite predicted at higher temperatures and low to medium pressure. On the other hand, in the pseudosection for composition $02 \mathrm{IV} 10 \mathrm{M}$ albite is not calculated to be stable along the covered $P-T$ range, and titanite only at a small field at $T<450{ }^{\circ} \mathrm{C}$ and $P \approx 8-9 \mathrm{kbar}$, while plagioclase is calculated to be stable only at pressures lower than 5-6 kbar.

Hornblende $\mathrm{Mg} /\left(\mathrm{Mg}+\mathrm{Fe}^{2+}\right)$ varies very little in both diagrams; $X_{\mathrm{Al}}{ }^{\mathrm{M} 2}$ and $(\mathrm{Na}+\mathrm{K})^{\mathrm{A}}$ variability is predicted to be controlled primarily by pressure, but, while for 02 IV $10 \mathrm{~A}$ both variables are calculated to increase with pressure, for $02 \mathrm{IV} 10 \mathrm{M}$ this trend is reversed after plagioclase reacts out. In both pseudosections plagioclase anorthite content is calculated to decrease with increasing pressure and garnet $\mathrm{Mg} /\left(\mathrm{Mg}+\mathrm{Fe}^{2+}\right)$ is predicted to increase with increasing temperature. Ca content in garnet is predicted to increase with increasing pressure and decreasing temperature, but the slope of the isopleths is reversed in orthopyroxene-bearing fields, and $\mathrm{Ca}$ is predicted to increase with decreasing pressure. In the case of hornblende $(\mathrm{Na}+\mathrm{K})^{\mathrm{A}}$ and $\mathrm{Mg} /\left(\mathrm{Mg}+\mathrm{Fe}^{2+}\right)$, garnet $\mathrm{Mg} /\left(\mathrm{Mg}+\mathrm{Fe}^{2+}\right)$ and plagioclase anorthite content, values that correspond to the ones observed in the metagabbros are calculated to overlap at $T<\approx 580{ }^{\circ} \mathrm{C}$ and $P$ between $\approx$ 3.5 and 6-7 kbar, regions of the $P-T$ space where orthopyroxene is predicted to be stable. The observed hornblende $X_{\mathrm{Al}}{ }^{\mathrm{M} 2}$ values are predicted to occur at pressures slightly lower than the stability field of garnet, while observed $\mathrm{Ca}$ contents in garnet are not predicted along the covered $P-T$ range.

\section{DISCUSSION}

In the case of $\mathrm{H}_{2} \mathrm{O}$-saturated conditions, typical amphibolite-facies metamafic rocks present the mineral assemblage hornblende + plagioclase + quartz \pm biotite \pm Ti-phase (Laird, 1980, Spear, 1981, Apted \& Liou, 1983) and commonly display textures that reflect chemical equilibrium on a hand-sample scale. The metamafic rocks from the Mantiqueira Complex studied here show a wide range of metamorphic textures and mineral assemblages, ranging from moderately hydrated rocks with partially preserved igneous texture and mineralogy (Figures 3-6) to fully hydrated amphibolites with typical metamorphic textures and mineral assemblages (Figure 
7). These rocks present mineral and textural features that give insights into the nature of metamorphic transformation of igneous protoliths.

\subsection{Occurrence of garnet-bearing rocks}

The main reaction textures observed consist of actinolitic hornblende pseudomorphs after clinopyroxene, mantled by pargasitic hornblende coronas, and garnet coronas around irregularshaped ilmenite crystals, separating them from plagioclase or hornblende. The simplest explanation for this kind of texture is that they represent the arrested development of metamorphic reactions whose product is the mineral assemblage present in the fully hydrated counterparts of these rocks. This line of reasoning works for the clinopyroxene-hornblende textures, but not for garnet, as it is absent from the amphibolites. If garnet cannot be explained as a product of the reactions that result in the mineral assemblage found in the fully hydrated amphibolites, then another, more complex explanation must be invoked. In discussions on reaction textures, emphasis is often put on the kinetic role of $\mathrm{H}_{2} \mathrm{O}$ (e.g. Rubie, 1986; Austrheim, 1987; White et al., 2008), as exemplified here by the fully hydrated samples being treated as fully equilibrated. However, $\mathrm{H}_{2} \mathrm{O}$ is also a system component, whose quantity will affect phase relations, just like the other oxides.

The amount of $\mathrm{H}_{2} \mathrm{O}$ likely varied in time and between and within samples, and such a variation must have the kinetic result of a variation in the equilibration volumes at different domains. This interplay between kinetics (the size of equilibration volumes) and thermodynamics (actual $\mathrm{H}_{2} \mathrm{O}$ quantities) is one of the factors that prevent the pseudosections presented from being used in a directly quantitative way. Qualitatively, the $P-X_{\mathrm{H}_{2} \mathrm{O}}$ and $T-X_{\mathrm{H}_{2} \mathrm{O}}$ pseudosections (Figures 18 , 19) show the $\mathrm{H}_{2} \mathrm{O}$ content to have a strong effect on the stability of garnet, which is more pronounced in the artificial composition that simulates the equilibration volume in the partially equilibrated rocks (02 IV 10M). This result is consistent with garnet occurring in the partially hydrated rocks but not in the fully hydrated ones. Orthopyroxene is predicted to be stable at similar $\mathrm{H}_{2} \mathrm{O}$ contents and is not present in the studied rocks, but the phase diagrams (Figures 1820) clearly predict an interplay between orthopyroxene and garnet stability. The stability of garnet in the calculated phase diagrams is likely underestimated due to the lack of $\mathrm{Mn}$ in the activitycomposition models used, as discussed in several works (e.g. Spear \& Cheney, 1989; Symmes \& Ferry, 1992; Droop \& Harte, 1995; Mahar, Baker, Powell, Holland \& Howell, 1997; White, Powell \& Johnson, 2014; Santos et al., 2019), so it is expected that, could Mn be considered, the 
predicted stability fields of garnet-bearing assemblages would expand at the expense of orthopyroxene. Clinopyroxene is also predicted to be stable at the relevant conditions. Although its predicted stability may have some effect on the predicted stability of garnet, which cannot be assessed at the moment, the calculations performed can still be taken as a reasonable approximation of the equilibrium relationships, so long as the restrictions placed by variations in equilibrium volume and activity-composition models are taken into account.

It is not possible, with the current data, to affirm that a garnet-bearing stage such as described here is the general case for the metamorphism of mafic rocks under variable $\mathrm{H}_{2} \mathrm{O}$ activity, but, should this be true, it would have implications for the assumed characteristics of mafic rocks under amphibolite-facies conditions, such as density and rheology.

\subsection{Textural features and mineral compositions}

While taking $\mathrm{H}_{2} \mathrm{O}$ content into consideration provides a likely explanation for the overall presence or absence of garnet in the rocks, it does not explain the textural features. As discussed in several works (e.g. Joesten, 1977; Ashworth \& Birdi, 1991; White et al., 2008; White \& Powell, 2011; Schorn \& Diener, 2017; Powell, Evans, Green \& White, 2018, 2019) metamorphic processes can be seen as changes in $P$ and $T$ causing gradients in chemical potentials, which are in turn flattened by diffusion. If one or more components do not diffuse fast enough to readily flatten these gradients, they can influence the spatial organization of the rock, even if equilibrium across the considered length scale is ultimately achieved (Carmichael, 1969; White et al., 2008, White \& Powell, 2011).

Among the most abundant elements in the Earth's crust, $\mathrm{Al}$ is commonly considered to be least mobile (e.g. Carlson, 2010; White et al, 2008; Štípská, Powell, White \& Baldwin, 2010) and is therefore the most likely to influence texture development. The Al content is one of the defining differences between the two groups of amphiboles identified in this work, hinting at low Al mobility. The spatial disposition of amphibole, with low-Al actinolitic hornblende pseudomorphs after clinopyroxene separated from plagioclase by high-Al pargasitic hornblende is also consistent with low Al mobility. From this, our interpretation of the clinopyroxene-amphibole textural relationships is that, initially, pargasitic hornblende started forming coronas between clinopyroxene and plagioclase, and, once clinopyroxene was separated from plagioclase (i.e. the Al source), it started being replaced by actinolitic hornblende, as Al was insufficiently mobile to 
form high-Al amphibole. Over time, this actinolitic hornblende would be converted to pargasitic hornblende as the slow diffusion of Al continued. Some observed features contribute to this interpretation: pargasitic hornblende in places occurs in direct contact with clinopyroxene, indicating it could form before actinolitic hornblende. Furthermore, the zoning in Al content observed in hornblende crystals from lineated metagabbro samples illustrate the continuation of the process, with diffusion converting actinolitic hornblende crystals into pargasitic hornblende from the outside inwards (see Figures 9c, d). The other components involved in this conversion are $\mathrm{Na}, \mathrm{Fe}^{2+}$ and $\mathrm{Mg}$, but, of these, $\mathrm{Na}$ diffusion can be readily discarded as a controlling factor, since it is generally regarded as one of the most mobile elements, and enters amphibole structure via coupled substitutions that involve $\mathrm{Al} . \mathrm{Fe}^{2+}$ and $\mathrm{Mg}$ require more careful consideration, but features such as the presence of pargasitic hornblende along plagioclase grain boundaries indicate that $\mathrm{Fe}^{2+}$ and $\mathrm{Mg}$ were fairly mobile. The mineral chemistry data obtained show the variation in $\mathrm{Mg} /\left(\mathrm{Mg}+\mathrm{Fe}^{2+}\right)$ to be proportional to the variation in $\mathrm{Al}$ content (Figure 8), so Al mobility controls the texture development and compositional variation in hornblende.

Garnet spatial distribution can also be explained by low Al diffusion, since garnet always forms near plagioclase, the only Al-bearing mineral of the igneous assemblage, and appears to largely grow into it. Garnet most commonly forms coronas around ilmenite, and that cannot be explained by $\mathrm{Al}$ diffusivity alone, but such textures are not uncommon (e.g. White \& Clarke, 1997). As ilmenite is Fe-rich, and also commonly one of the more Mn-rich minerals in rocks (Frost \& Lindsey, 1991; White et al 2014b), it likely provides an ideal nucleation site for garnet (e.g. White \& Clarke, 1997).

\subsection{Development of the fully hydrated rocks}

The previous discussion explains mineralogical and textural features of the partially hydrated rocks, but does it bear importance to the development of the fully hydrated samples? In other words, did the amphibolites experience a stage correspondent to the metagabbro? Or they evolved from gabbro in a different way? Textural features observed in the fully hydrated amphibolites point to the former answer: actinolitic hornblende with pargasitic rims is still observed in these samples (Figure 7c), as is relict igneous tabular plagioclase. However, garnet is practically absent in the amphibolite, and no textural features point to its former presence, so the evolution of the different samples was similar, but not necessarily identical. Additionally, textural 
and mineral chemistry data show that the conversion of clinopyroxene to actinolitic hornblende and then pargasitic hornblende is not a simple, one-stage process: the initially-formed pargasitic hornblende is "more pargasitic" than the equilibrium compositions measured in the amphibolite, and both amphibolite and lineated metagabbro samples present some crystals with zoning that is opposite to what is normally observed, i.e. crystals with high-Al cores and low-Al rims. These crystals are interpreted to represent the process of Al diffusing away from the initially formed, high-Al crystals (see Figures 7c, 9).

\section{CONCLUSIONS}

Metagabbro samples from Mantiqueira Complex present a coherent picture of the transformation of gabbro to amphibolite, with changes in texture and mineral assemblage driven by $\mathrm{H}_{2} \mathrm{O}$ ingress. The details of this transformation are recorded by the reaction textures developed in these rocks. The presence of garnet in the metagabbro and its absence from the amphibolite can be ascribed to the limited amount of $\mathrm{H}_{2} \mathrm{O}$ that equilibrated with the mineral assemblage in the metagabbros, in contrast to the fully hydrated amphibolites. Other features, such as the presence of actinolitic hornblende pseudomorphs after pyroxene, the spatial distribution of garnet, and the presence of hornblende in contacts between plagioclase grains can be ascribed to the low mobility of $\mathrm{Al}$ in contrast to the higher mobility of other components, especially $\mathrm{Fe}$ and $\mathrm{Mg}$.

Since clinopyroxene is one of the essential mineral phases of mafic igneous rocks, and hornblende is one of the essential mineral phases of amphibolite facies mafic rocks, the substitution process described here and the explanation given to it can likely be treated as general case for the metamorphism of gabbro/basalt at amphibolite facies conditions, under variable $\mathrm{H}_{2} \mathrm{O}$ activity. The textures involving garnet may not be so general, though, as it is not clear if all samples did have garnet at some point of their evolution, and the control that factors such as bulkrock composition, $P, T$ and $X_{\mathrm{H}_{2} \mathrm{O}}$ exert over garnet stability in mafic rocks need to be known more clearly.

In many works, the amount of $\mathrm{H}_{2} \mathrm{O}$ is not considered a controlling variable, be it because it is considered to be in excess (see examples in Spear, 1993 and Bucher \& Grapes, 2011 among many others) or because it is present in very low quantities (e.g Ashworth, Shelplev, Bryxina, Kobolov \& Reverdatto, 1998; Jamtveit, Bucher-Nurminen \& Austrheim, 1990; Schorn \& Diener 
2017). In the example studied here, $\mathrm{H}_{2} \mathrm{O}$ plays a critical role not only as a kinetic factor, but also as a component whose quantity affects equilibrium relationships.

The persistence of igneous plagioclase and chemically zoned hornblende crystals even in the more hydrated, texturally equilibrated rocks, indicates that such medium-grained anhydrous rocks have difficulty in attaining thin section-scale chemical equilibrium even when subject to intense deformation and water influx.

\section{ACKNOWLEDGEMENTS}

The authors thank David Pattison and four anonymous reviewers for the constructive reviews, and Katy Evans for her editorial work. G. Queiroga is thanked for her useful suggestions. This study was supported by FAPESP (processes $n^{\circ}$ 13/04007-0 and 16/22627-3). C. A. Santos received a $\mathrm{PhD}$ scholarship from $\mathrm{CNPq}$.

\section{REFERENCES}

Alkmin, F. F.; Kuchenbecker, M.; Reis, H. L. S. \& Pedrosa-Soares, A. C. (2017). The Araçuaí Belt. In: Heilbron, M.; Cordani, U. G. \& Alkmim, F. F. (eds.) São Francisco Craton, Eastern Brazil. Tectonic Genealogy of a Miniature Continent. Cham. Springer. p. 255-276.

Apted, M. J. \& Liou, J. G. (1983). Phase relations amongst greenschist, epidote-amphibolite, and amphibolite in a basaltic system. American Journal of Science. 283A:328-354.

Ashworth, J. R.; Shelplev, V. S.; Bryxina, N. A.; Kolobov, V. Y. \& Reverdatto, V. V. (1998). Diffusion-controlled corona reaction and over-stepping of equilibrium in a garnet granulite, Yenisey Ridge, Siberia. Journal of Metamorphic Geology. 16:231-246.

Ashworth, J. R \& Birdi, J. J. (1990). Diffusion modeling of coronas around olivine in an open system. Geochimica et Cosmochimica Acta. 54:2389-2401.

Austrheim, H. (1987). Eclogitization of lower crustal granulites by fluid migration through shear zones. Earth and Planetary Science Letters. 81:221-232.

Baltazar, O. F. \& Raposo, F. O. (orgs) (1993). Geologia da folha Mariana - Programa de levantamentos geológicos básicos do Brasil. Brasília. Convênio DNPM/CPRM. 183p.

This article is protected by copyright. All rights reserved 
Brueckner, H. K.; Cunningham, D.; Alkmin, F. F. \& Marshak, S. (2000). Tectonic implications of Precambrian Sm-Nd dates from the southern São Francisco craton and adjacent Araçuaí and Ribeira belts, Brazil. Precambrian Research. 99:255-269.

Bucher, K. \& Grapes, R. (2011). Petrogenesis of Metamorphic Rocks. Heidelberg. SpringerVerlag. 428p.

Carlson, W. D. (2010). Dependence of reaction kinetics on $\mathrm{H}_{2} \mathrm{O}$ activity as inferred from rates of intergranular diffusion of aluminium. Journal of Metamorphic Geology. 28:735-752.

Carmichael, D. M. (1969). On the mechanism of prograde metamorphic reactions in quartzbearing pelitic rocks. Contributions to Mineralogy and Petrology. 20:244-267.

Cutts, K.; Lana, C.; Alkmim, F.; \& Peres, G. G. (2018). Metamorphic imprints on units of the southern Araçuaí Belt, SE Brazil: The history of superimposed Transamazonian and Brasiliano orogenesis. Gondwana Research. 58:211-234.

Diener, J. F. A. \& Powell, R. (2010). Influence of ferric iron on the stability of mineral assemblages. Journal of Metamorphic Geology. 28:599-613.

Droop, G. T. R. (1987). A general equation for estimating $\mathrm{Fe}^{3+}$ concentrations in ferromagnesian silicates and oxides from microprobe analyses, using stoichiometric criteria. Mineralogical Magazine. 51:431-435.

Droop, G. T. R. \& Harte, B. (1995). The effect of Mn on the phase relations of medium-grade pelites: constraints from natural assemblages on petrogenetic grid topology. Journal of Petrology. 36:1549-1578.

Droop, G. T. R. \& Brodie, K. H. (2012). Anatectic melt volumes in the thermal aureole of the Etive Complex, Scotland: the roles of fluid-present and fluid-absent melting. Journal of Metamorphic Geology. 30:843-864.

Duarte, B. P.; Valente, S. C.; Heilbron, M.; \& Campos Neto, M. C. (2004). Petrogenesis of the Orthogneisses of the Mantiqueira Complex, Central Ribeira Belt, SE Brazil: An Archaean to Palaeoproterozoic Basement Unit Reworked During the Pan-African Orogeny. Gondwana Research. 7:437-450. 
Figueiredo, M. C. H. \& Teixeira, W. (1996). The Mantiqueira Metamorphic Complex, eastern Minas Gerais state: Preliminary geochronological and geochemical results. Anais da Academia Brasileira de Ciências. 68: 223-246.

Forshaw, J. B.; Waters, D. J.; Pattison, D. R. M.; Palin, R. M. \& Gopon, P. (2019). A comparison of observed and thermodynamically predicted phase equilibria and mineral compositions in mafic granulites. Journal of Metamorphic Geology. 37:153-179.

Frost, B. R. \& Lindsey, D. H. (1991). Occurrence of iron-titanium oxides in igneous rocks. Reviews in Mineralogy and Geochemistry. 25:433-468.

Green, E. C. R.; White, R. W.; Diener, J. F. A.; Powell, R.; Holland, T. J. B. \& Palin, R. M. (2016). Activity-composition relations for the calculation of partial melting equilibria in metabasic rocks. Journal of Metamorphic Geology. 34:845-869.

Hawthorne, F. C.; Oberti, R.; Harlow, G. E.; Maresch, W. V.; Martin, R. F.; Schumacher, J. C., ... Welch, M. D. (2012). Nomenclature of the amphibole supergroup. American Mineralogist. 97:2031-2048.

Holland, T. J. B. \& Powell, R. (2011) An improved and extended internally consistent thermodynamic dataset for phases of petrological interest, involving a new equation of state for solids. Journal of Metamorphic Geology. 29:333-383.

Jamtveit, B.; Bucher-Nurminen, K \& Austrheim, H. (1990). Fluid controlled eclogitization of granulites in deep crustal shear zones, Bergen Arcs, western Norway. Contributions to Mineralogy and Petrology. 104:184-193.

Joesten, R. (1977). Evolution of mineral assemblage zoning in diffusion metasomatism. Geochimica et Cosmochimica Acta. 47:283-294.

Laird, J. (1980). Phase equilibria in mafic schist from Vermont. Journal of Petrology. 21: 1-37.

Leake, B. E.; Woolley, A. R.; Arps, C. E. S.; Birch, W. D.; Gilbert, M. C.; Grice, J. D., ... Guo, Y. (1997). Nomenclature of amphiboles: Report of the subcommittee on amphiboles of the International Mineralogical Association, Commission of New Minerals and Mineral Names. Canadian Mineralogist. 35:219-246. 
Le Maitre, R. W.; Bateman, P.; Dudek, A.; Keller, J.; Le Bas, M. J. L.; Sabine, P. A., ... Zannetin, B. (1989). A classification of igneous rocks and glossary of terms. Oxford. Blackwell. 236p.

Mahar, E. M.; Baker, J .M.; Powell, R.; Holland, T. J. B. \& Howell, N. (1997). The effect of Mn on mineral stability in metapelites. Journal of Metamorphic Geology. 15:223-238.

Mori, P. E.; Reeves, S.; Correia, C. T.\& Haukka, M. (1999). Development of a fused glass disc XRF facility and comparison with the pressed powder pellet technique at Instituto de Geociências, São Paulo University. Revista Brasileira de Geociências.19:441-446.

Nicollet, C. \& Goncalves, P. (2005). Two contrasted P-T-time paths of coronitic metanorites of the French Massif Central: are reaction textures reliable guides to metamorphic histories ? Journal of Metamorphic Geology. 23:97-105.

Noce, C. M.; Pedrosa-Soares, A. C.; Silva, L. C.; Armstrong, R. \& Piuzana, D. (2007). Evolution of polycyclic basement in the Araçuaí Orogen, based on U-Pb SHRIMP data: implications for the Brazil-Africa links in the Paleoproterozoic time. Precambrian Research 159: 60-78.

Pearce, M. A.; White, A. J. R. \& Gazley, M. F. (2015). TCInvestigator: automated calculation of mineral mode composition contours for THERMOCALC pseudosections. Journal of Metamorphic Geology. 33:413-425.

Powell, R. \& Holland, T. J. B. (1988). An internally consistent dataset with uncertainties and correlations: 3. Applications to geobarometry, worked examples and a computer program. Journal of Metamorphic Geology. 6:173-204.

Powell, R.; Evans, K. A.; Green, E. C. R. \& White, R. W. (2018). On equilibrium in nonhydrostatic metamorphic systems. Journal of Metamorphic Geology. 36:419-438.

Powell, R.; Evans, K. A.; Green, E. C. R. \& White, R. W. (2019). The truth and beauty of chemical potentials. Journal of Metamorphic Geology. 37:1007-1019.

Rivers, T. \& Mengel, F. C. (1988). Contrasting assemblages and petrogenetic evolution of corona and noncorona gabbros in the Grenville Province of western Labrador. Canadian Journal of Earth Sciences. 25:1629-1648. 
Rubie, D. C. (1986). The catalysis of mineral reactions by water and restrictions on the presence of aqueous fluid during metamorphism. Mineralogical Magazine. 50:399-415.

Santos, C. A., Moraes, R. M. \& Szabó, G. A. J. (2019). A comparison between phase diagram modelling of metamafic rocks and experimental and independent thermobarometric data. Lithos. 340-341:108-123.

Schorn, S. \& Diener, J. F. A. (2017). Details of the gabbro-to-eclogite transition determined from microtextures and calculated chemical potential relationships. Journal of Metamorphic Geology. 35:55-75.

Silva, L. C.; Armstrong, R.; Noce, C. M.; Carneiro, M. A.; Pimentel., M.; Pedrosa-Soares, A. C.; ... Cardoso Filho, J. M. (2002). Reavaliação da evolução geológica de terrenos pré-cambrianos brasileiros com base em novos dados U-Pb shrimp, parte II: Orógeno Araçuaí, Cinturão Mineiro e Cráton São Francisco Meridional. Revista Brasileira de Geociências. 32:513-528.

Spear, F. S. (1981). An experimental study of hornblende stability and compositional variability in amphibolite. American Journal of Science. 281:697-934.

Spear, F. S. (1993). Metamorphic Phase Equilibria and Pressure-Temperature-Time Paths. Washington D. C. Mineralogical Society of America. 799p.

Spear, F. S. \& Cheney, J. T. (1989). A petrogenetic grid for pelitic schists in the system $\mathrm{SiO}_{2}$ $\mathrm{Al}_{2} \mathrm{O}_{3}-\mathrm{FeO}-\mathrm{MgO}-\mathrm{K}_{2} \mathrm{O}-\mathrm{H}_{2} \mathrm{O}$. Contributions to Mineralogy and Petrology. 101:149-164.

Štípská, P; Powell, R.; White, R. W. \& Baldwin, J. A. (2010). Using chemical potential relationships to account for coronas around kyanite: an example from the Bohemian Massif. Journal of Metamorphic Geology. 28:97-116.

Symmes, G. H. \& Ferry, J. M. (1992). The effect of whole-rock MnO content on the stability of garnet in pelitic schists during metamorphism. Journal of Metamorphic Geology. 10:221-237.

Weinberg, R. F. \& Hasalová, P. (2015). Water-fluxed melting of the continental crust: a review. Lithos. 212-215:158-188. 
White, R. W.; Powell, R. \& Holland, T. J. B. (2001). Calculation of partial melting equilibria in the system $\mathrm{Na}_{2} \mathrm{O}-\mathrm{CaO}-\mathrm{K}_{2} \mathrm{O}-\mathrm{FeO}-\mathrm{MgO}-\mathrm{Al}_{2} \mathrm{O}_{3}-\mathrm{SiO}_{2}-\mathrm{H}_{2} \mathrm{O}$ (NCKFMASH). Journal of Metamorphic Geology. 19:139-153.

White, R. W.; Powell, R. \& Baldwin, J. A. (2008). Calculated phase equilibria involving chemical potentials to investigate the textural evolution of metamorphic rocks. Journal of Metamorphic Geology. 26: 181-198.

White, R. W.; Powell; R.; Holland, T. J. B.; Johnson, T. E. \& Green, E. C. R. (2014a). New mineral activity-composition relations for thermodynamic calculations in metapelitic systems. Journal of Metamorphic Geology. 32:261-286.

White, R. W.; Powell; R. \& Johnson, T. E (2014b). The effect of Mn in mineral stability in metapelites revisited: new $a-x$ relations for manganese-bearing minerals. Journal of Metamorphic Geology. 32:809-828.

White, R. W. \& Clarke, G. L. (1997). The role of deformation in aiding recrystallization: an example from a high-pressure shear zone, central Australia. Journal of Petrology. 38:1307-1329.

White, R. W. \& Powell, R. (2011). On the interpretation of retrograde reaction textures in granulite facies rocks. Journal of Metamorphic Geology. 29: 131-149.

Whitney, P. R. \& McLelland, J. M. (1983). Origin of biotite-hornblende-garnet coronas between oxides and plagioclase in olivine metagabbros, Adirondack region, New York. Contributions to Mineralogy and Petrology. 82:34-41.

\section{SUPPORTING INFORMATION}

Additional Supporting Information may be found online in the supporting information tab for this article.

Table S1. Hornblende mineral chemistry data

Table S2. Plagioclase mineral chemistry data

Table S3. Clinopyroxene mineral chemistry data

Table S4. Garnet mineral chemistry data 
Table S5. Biotite mineral chemistry data

Table S6. Ilmenite mineral chemistry data

Figure S1. Chemical variation of hornblende from samples 09-VIII-8A (a, c, e) and PNF 01A (b, d, f).

Figure S2. $P-T$ pseudosections calculated for the composition of sample PNF 01B, assuming $X_{\mathrm{Fe}^{3+}}$ $=0.18$ (as in figure 15a), with additional sets of isopleths.

Figure S3. P-T pseudosections constructed for the composition of sample PNF 01B, assuming $X_{\mathrm{Fe}^{3+}}=0.15$ (as in figure 15b), with additional sets of isopleths.

Figure S4. P-T pseudosections constructed for the composition of sample PNF 01B, assuming $X_{\mathrm{Fe}^{3+}}=0.09$ (as in figure 16a), with additional sets of isopleths.

Figure S5. $P-T$ pseudosections constructed for the composition of sample PNF 01B, assuming $X_{\mathrm{Fe}^{3+}} \approx 0$ (as in figure 16b), with additional sets of isopleths.

Figure S6. (a) $T$ - $X_{\mathrm{H}_{2} \mathrm{O}}$ pseudosection constructed for composition of sample PNF 01B, assuming $X_{\mathrm{Fe}^{3+}}=0.18$ (as in figure 15a). (b) $P-X_{\mathrm{H}_{2} \mathrm{O}}$ pseudosection constructed for composition of sample PNF 01B, assuming $X_{\mathrm{Fe}^{3+}}=0.18$ (as in figure 15a).

Figure S7. (a) $T$ - $X_{\mathrm{H}_{2} \mathrm{O}}$ pseudosection constructed for composition of sample PNF 01B, assuming $X_{\mathrm{Fe}^{3+}}=0.15$ (as in figure 15b). (b) $P-X_{\mathrm{H}_{2} \mathrm{O}}$ pseudosection constructed for composition of sample PNF 01B, assuming $X_{\mathrm{Fe}^{3+}}=0.15$ (as in figure 15b).

Figure S8. (a) $T$ - $X_{\mathrm{H}_{2} \mathrm{O}}$ pseudosection constructed for composition of sample PNF 01B, assuming $X_{\mathrm{Fe}^{3+}}=0.09$ (as in figure 16a). (b) $P-X_{\mathrm{H}_{2} \mathrm{O}}$ pseudosection constructed for composition of sample PNF 01B, assuming $X_{\mathrm{Fe}^{3+}}=0.09$ (as in figure 16a).

Figure S9. (a) $T$ - $X_{\mathrm{H}_{2} \mathrm{O}}$ pseudosection constructed for composition of sample PNF 01B, assuming $X_{\mathrm{Fe}^{3+}} \approx 0$ (as in figure 16b). (b) $P-X_{\mathrm{H}_{2} \mathrm{O}}$ pseudosection constructed for composition of sample PNF $01 \mathrm{~B}$, assuming $X_{\mathrm{Fe}^{3+}} \approx 0$ (as in figure $16 \mathrm{~b}$ ). 
Figure S10. (a) $T-X_{\mathrm{H}_{2} \mathrm{O}}$ pseudosection constructed for composition of sample $02 \mathrm{IV} 10 \mathrm{~A}$ (as in figure 18a), with additional isopleths. (b) $P-X_{\mathrm{H}_{2} \mathrm{O}}$ pseudosection constructed for composition of sample 02 IV 10A (as in figure 18b), with additional isopleths.

Figure S11. (a) $T$ - $X_{\mathrm{H}_{2} \mathrm{O}}$ pseudosection constructed for composition $02 \mathrm{IV} 10 \mathrm{M}$ (as in figure 19a), with additional isopleths. (b) $P-X_{\mathrm{H}_{2} \mathrm{O}}$ pseudosection constructed for composition 02 IV $10 \mathrm{M}$ (as in figure 19b), with additional isopleths.

Figure S12. $P-T$ pseudosection calculated for the composition of sample PNF 01B, assuming $\mathrm{H}_{2} \mathrm{O}$ $=3.5 \mathrm{~mol} \%$ (the same as used in the pseudosections in figure 20 ).

Figure S13. (a) $P-T$ pseudosection calculated for the composition of sample 02 IV $10 \mathrm{~A}$, assuming $\mathrm{H}_{2} \mathrm{O}=3.5 \mathrm{~mol} \%$ (as in figure 20a), with additional isopleths. (b) $P-T$ pseudosection calculated for composition $02 \mathrm{IV} 10 \mathrm{M}$, assuming $\mathrm{H}_{2} \mathrm{O}=3.5 \mathrm{~mol} \%$ (as in figure $20 \mathrm{~b}$ ), with additional isopleths.

\section{FIGURE CAPTIONS}

Figure 1. Geological context of the studied samples. Maps by Cutts, et al. (2018).

Figure 2. Chemical compositions of the studied samples plotted on the diagram for classification of volcanic rocks of Le Maitre et al. (1989).

Figure 3. (a) general aspect of the metagabbro. (b) fine-grained plagioclase in the rims of tabular, igneous plagioclase. (c) cummingtonite exsolution lamellae (brighter) in actinolitic hornblende crystals (darker) in metagabbro sample. Backscattered electron image. (d) a combination of different reaction textures in a metagabbro sample: part of the ilmenite aggregate is mantled by garnet (bottom) and part is mantled by pargasitic hornblende (top). The pargasitic hornblende mantle actually separates the ilmenite aggregate from an actinolitic hornblende pseudomorph after clinopyroxene (top-left). (e) replacement of pyroxene by actinolitic hornblende along micrometric planes in metagabbro sample. Backscattered electron image. (f) pargasitic hornblende in fractures and contacts between plagioclase crystals in metagabbro sample. 
Figure 4. Textural features in metagabbro samples, as simplified sketches (left) and photomicrographs or backscattered electron images (right). (a-b) actinolitic hornblende pseudomorph after clinopyroxene, mantled by pargasitic hornblende (top), metamorphic plagioclase at igneous plagioclase rims (center-left) and ilmenite crystal mantled by pargasitic hornblende (top-right). (c-d) clinopyroxene crystal partially replaced by actinolitic hornblende and mantled by pargasitic hornblende. (e-f) ilmenite mantled by garnet, and garnet in contact between hornblende and plagioclase.

Figure 5. (a) general aspect of the lineated metagabbro. (b) hornblende aggregate in lineated metagabbro. Backscattered electron image. (c) elongate garnet crystal in lineated metagabbro. (d) clinopyroxene crystal, partially replaced by actinolitic hornblende and wrapped around by the lineation.

Figure 6. Textural features in lineated metagabbro samples, as simplified sketches (left) and photomicrographs or backscattered electron images (right). (a-b) igneous plagioclase remnants in metamorphic plagioclase aggregate in lineated metagabbro sample. (c-d) ilmenite mantled by garnet in lineated metagabbro sample.

Figure 7. (a) general aspect of the amphibolite. (b) polygonal plagioclase crystals in amphibolite sample. (c) polygonal pargasitic hornblende crystals in amphibolite sample. Note the presence of two types of zoning: with actinolitic (darker) cores (top-center, up left corner) and with pargasitic (brighter) cores (bottom-center). Both $\mathrm{b}$ and $\mathrm{c}$ are backscattered electron images.

Figure 8. Chemical variation of hornblende from metagabbro sample 05-III-20 (a, c, e) and from lineated metagabbro sample 09-XII-8B (b, d, f).

Figure 9. WDS compositional maps showing the abundance of $\mathrm{Al}$ in textures from metagabbro and lineated metagabbro samples. Black areas correspond to pyroxene, quartz or cummingtonite, white to red areas correspond to plagioclase, while dark blue to green areas correspond to hornblende. (a-b) metagabbro samples. (c-d) lineated metagabbro samples.

Figure 10. Chemical variation of hornblende in amphibolite.

Figure 11. Chemical variation of plagioclase.

Figure 12. Chemical variation of clinopyroxene and garnet. 
Figure 13. WDS compositional maps of a garnet crystal from a metagabbro sample, showing abundances of calcium (a) and iron (b).

Figure 14. Chemical variation of biotite.

Figure 15. $P-T$ pseudosections constructed for the composition of sample PNF 01B, assuming $X_{\mathrm{Fe}^{3+}}=0.18(\mathrm{a})$ and $X_{\mathrm{Fe}^{3+}}=0.15(\mathrm{~b})$.

Figure 16. $P-T$ pseudosections constructed for the composition of sample PNF 01B, assuming $X_{\mathrm{Fe}^{3+}}=0.09$ (a) and $X_{\mathrm{Fe}^{3+}} \approx 0(\mathrm{~b})$.

Figure 17. $P-T$ pseudosections constructed for the composition of sample 02-IV-10A (a) and for composition 02 IV 10M (b).

Figure 18. (a) $T$ - $X_{\mathrm{H}_{2} \mathrm{O}}$ pseudosection constructed for composition of sample 02-IV-10A. (b) $P$ $X_{\mathrm{H}_{2} \mathrm{O}}$ pseudosection constructed for composition of sample 02-IV-10A.

Figure 19. (a) $T$ - $X_{\mathrm{H}_{2} \mathrm{O}}$ pseudosection constructed for composition $02-\mathrm{IV}-10 \mathrm{M}$. (b) $P-X_{\mathrm{H}_{2} \mathrm{O}}$ pseudosection constructed for composition 02-IV-10M.

Figure 20. $P-T$ pseudosections constructed for the composition of sample 02-IV-10A (a) and for composition $02 \mathrm{IV} 10 \mathrm{M}(\mathrm{b})$, assuming $\mathrm{H}_{2} \mathrm{O}=3.5 \mathrm{~mol} \%$.

Table captions

Table 1. Whole rock analyses of metamafic rock samples from Mantiqueira Complex. Values are in $w t^{\%} \%$.

This article is protected by copyright. All rights reserved 
Table 1

\begin{tabular}{c|c|c|c|c|c|c|c}
\hline Sample & PNF 01A & 02 IV 10A & 06 IX 54 & 06 X 66 & 07 II 08 & 07 III 07C & PNF 01B \\
\hline Rock type & Metag & Metag & Amph & Amph & Metag & L. metag & Amph \\
\hline $\mathrm{SiO}_{2}$ & 47.87 & 49.46 & 48.98 & 49.14 & 49.09 & 49.30 & 50.50 \\
\hline $\mathrm{TiO}_{2}$ & 2.49 & 2.11 & 2.35 & 2.02 & 2.02 & 2.22 & 1.47 \\
\hline $\mathrm{Al}_{2} \mathrm{O}_{3}$ & 13.68 & 13.93 & 13.84 & 13.98 & 13.87 & 13.88 & 14.36 \\
\hline $\mathrm{FeO}$ & 11.52 & 10.77 & 11.34 & 11.47 & 10.43 & 10.43 & 8.89 \\
\hline $\mathrm{Fe}_{2} \mathrm{O}_{3}$ & 2.84 & 1.91 & 1.77 & 1.65 & 2.02 & 2.44 & 2.17 \\
\hline $\mathrm{MnO}$ & 0.22 & 0.21 & 0.21 & 0.22 & 0.21 & 0.21 & 0.18 \\
\hline $\mathrm{MgO}$ & 6.84 & 6.49 & 6.27 & 6.34 & 6.89 & 6.49 & 7.14 \\
\hline $\mathrm{CaO}$ & 10.78 & 10.89 & 10.35 & 10.56 & 11.21 & 10.67 & 11.22 \\
\hline $\mathrm{Na}_{2} \mathrm{O}$ & 2.09 & 2.43 & 2.26 & 2.17 & 2.31 & 2.34 & 2.20 \\
\hline $\mathrm{K}_{2} \mathrm{O}$ & 0.41 & 0.52 & 0.52 & 0.54 & 0.46 & 0.65 & 0.62 \\
\hline $\mathrm{P}_{2} \mathrm{O}_{5}$ & 0.17 & 0.23 & 0.23 & 0.26 & 0.20 & 0.24 & 0.17 \\
\hline $\mathrm{Lol}$ & 0.02 & 0.26 & 0.29 & 0.17 & 0.02 & 0.45 & 0.72 \\
\hline $\mathrm{Total}^{2}$ & 98.64 & 99.02 & 98.23 & 98.34 & 98.53 & 99.07 & 98.92 \\
\hline
\end{tabular}




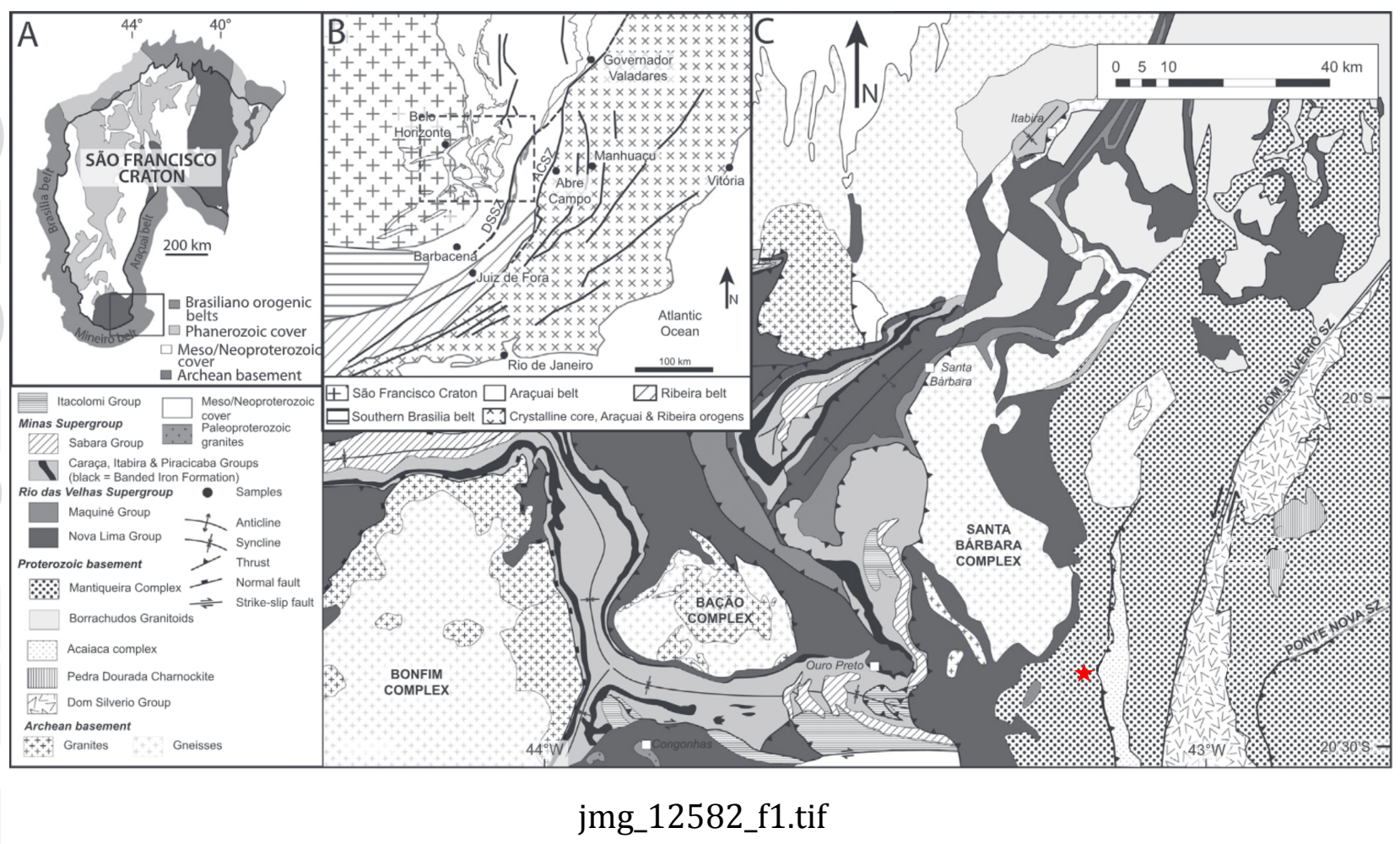

This article is protected by copyright. All rights reserved 


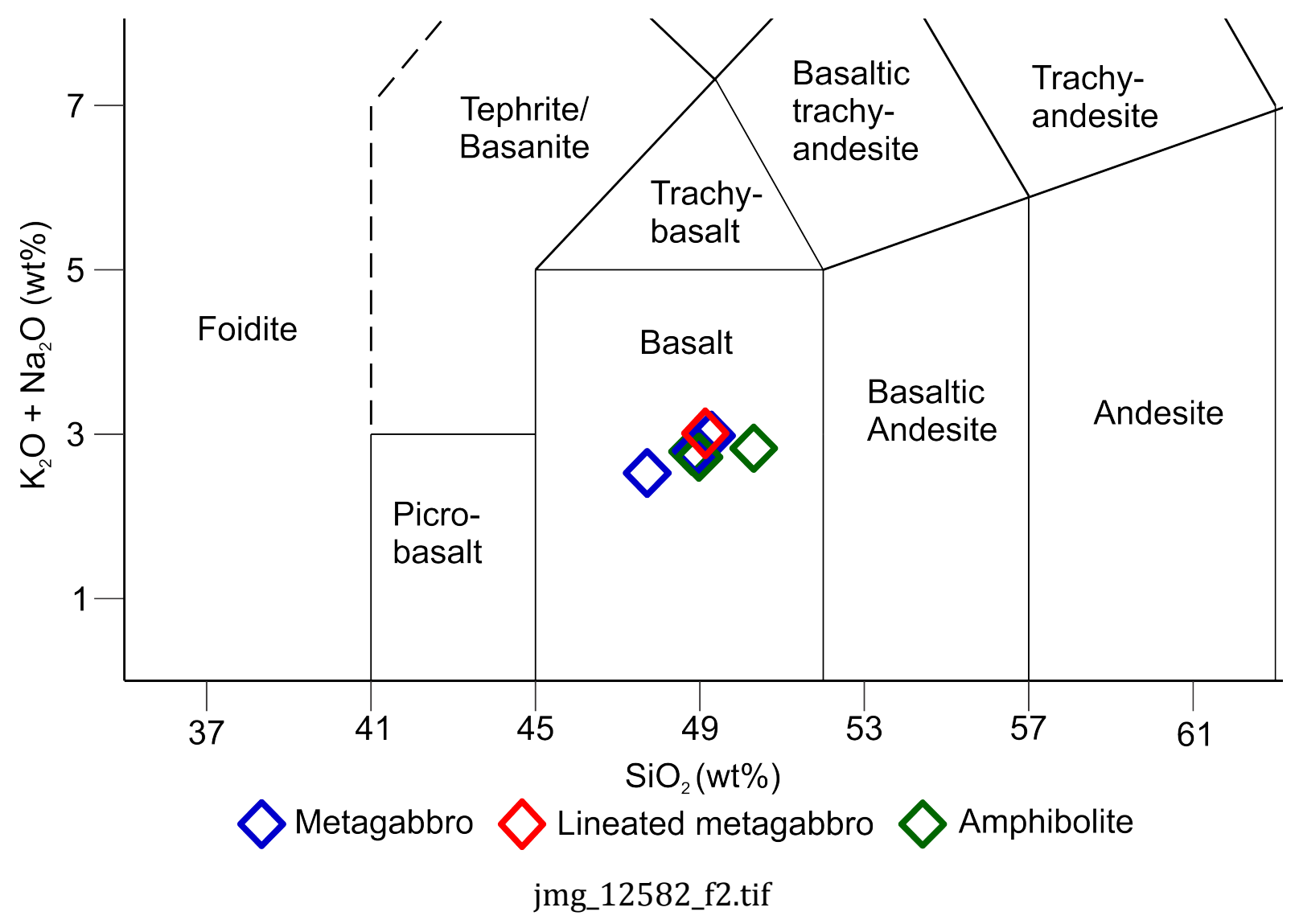

This article is protected by copyright. All rights reserved 

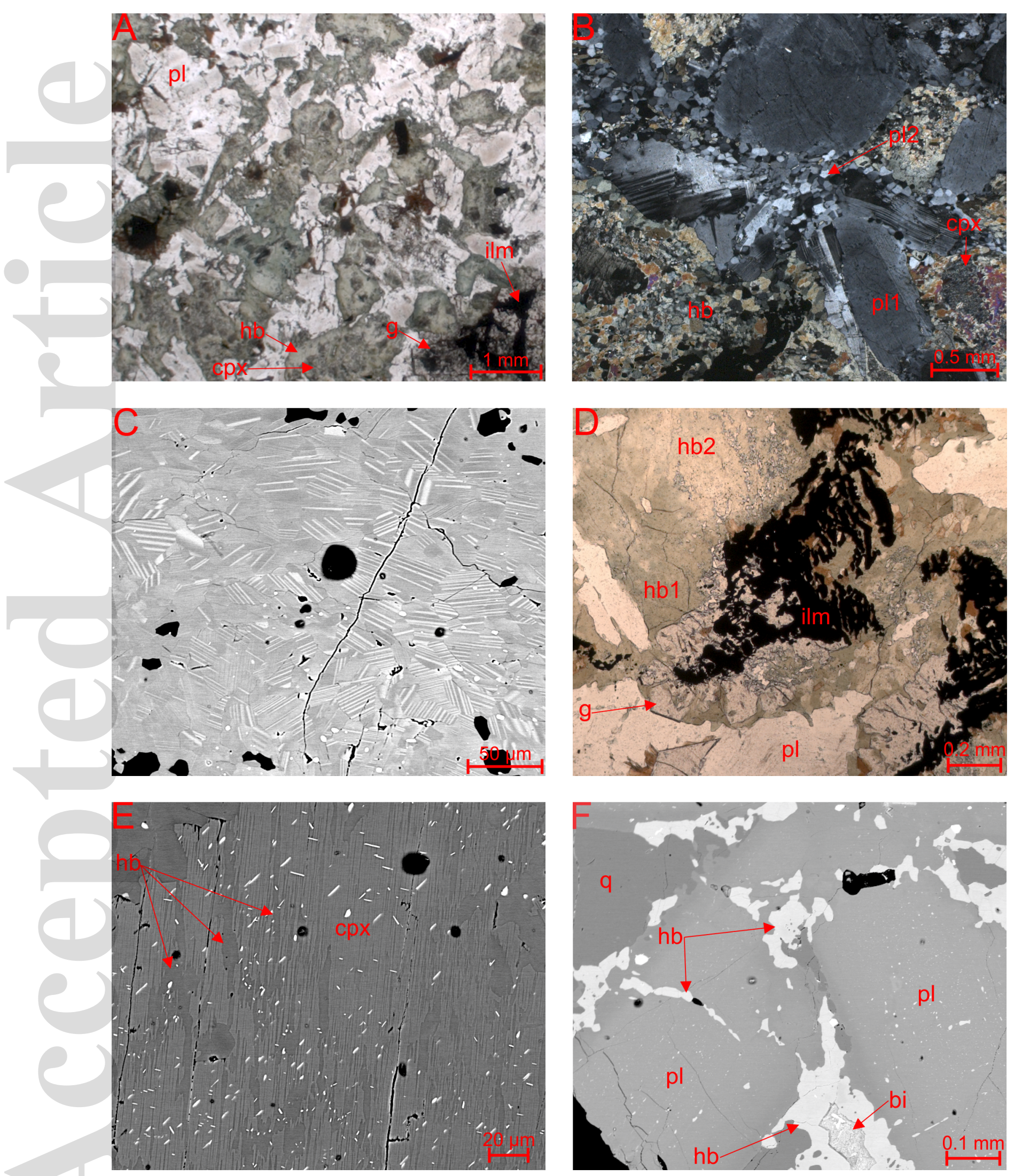

jmg_12582_f3.tif

This article is protected by copyright. All rights reserved 

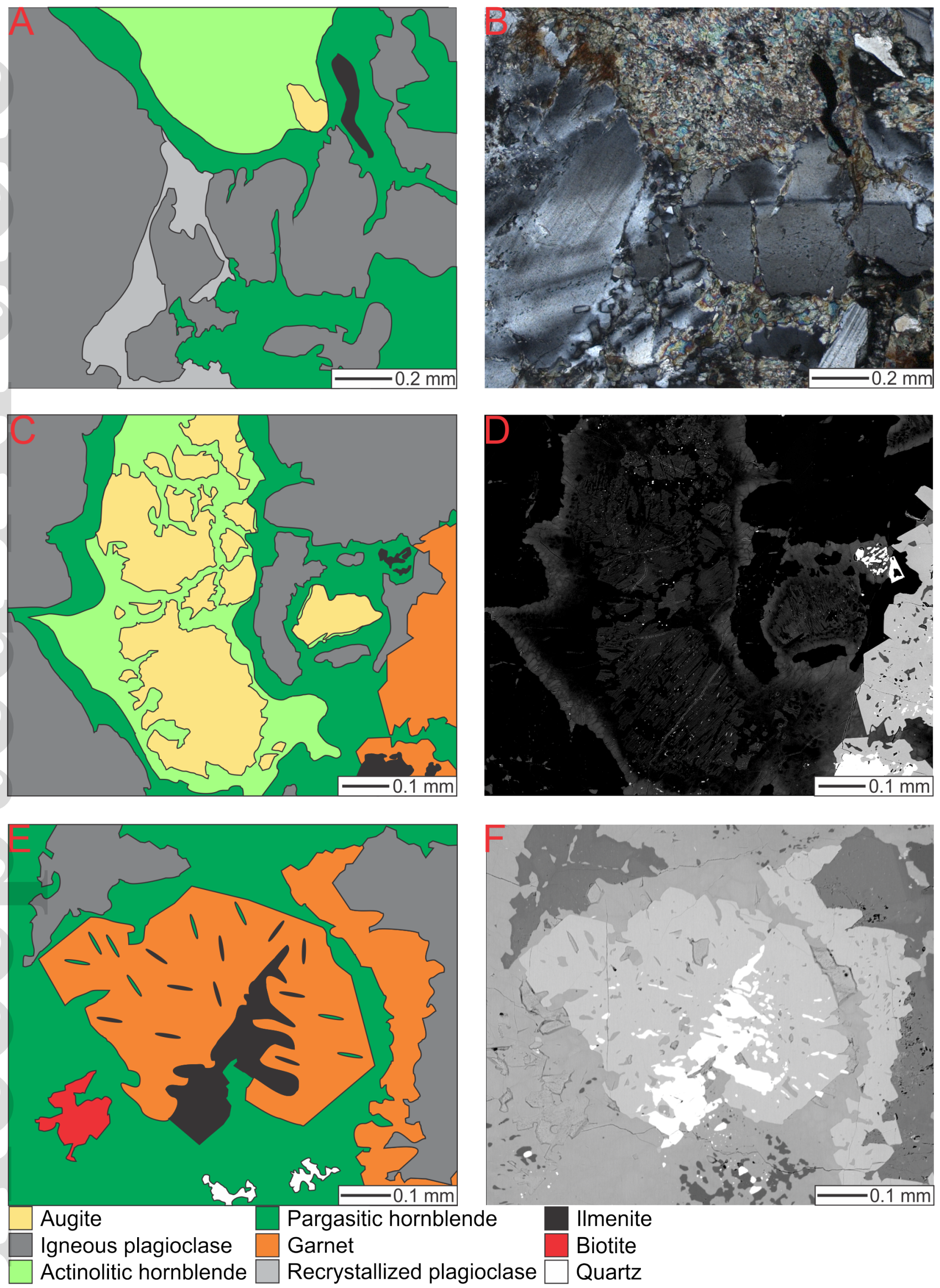

Garnet

Recrystallized plagioclase $\square$ Quartz

jmg_12582_f4.tif

This article is protected by copyright. All rights reserved 


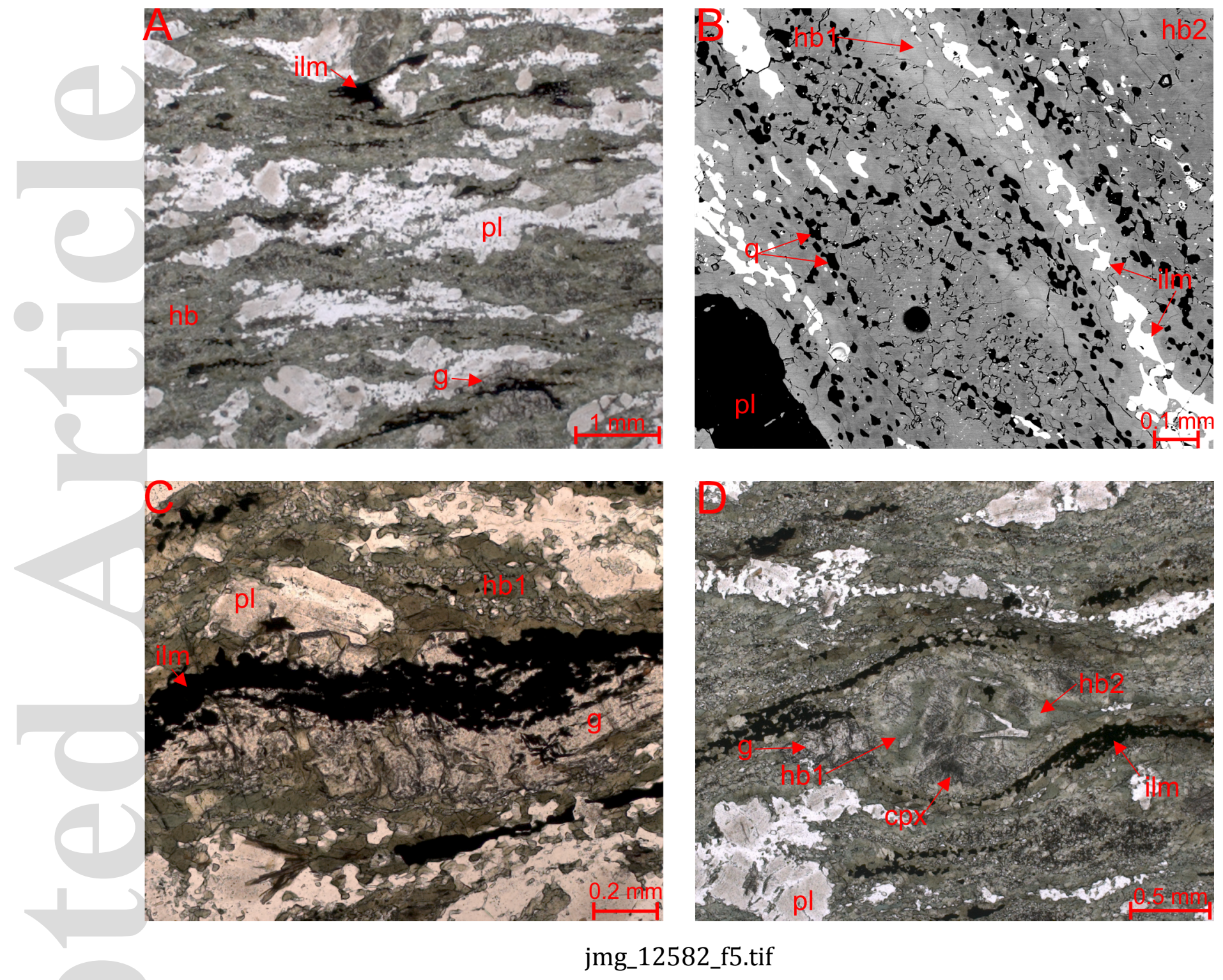

This article is protected by copyright. All rights reserved 

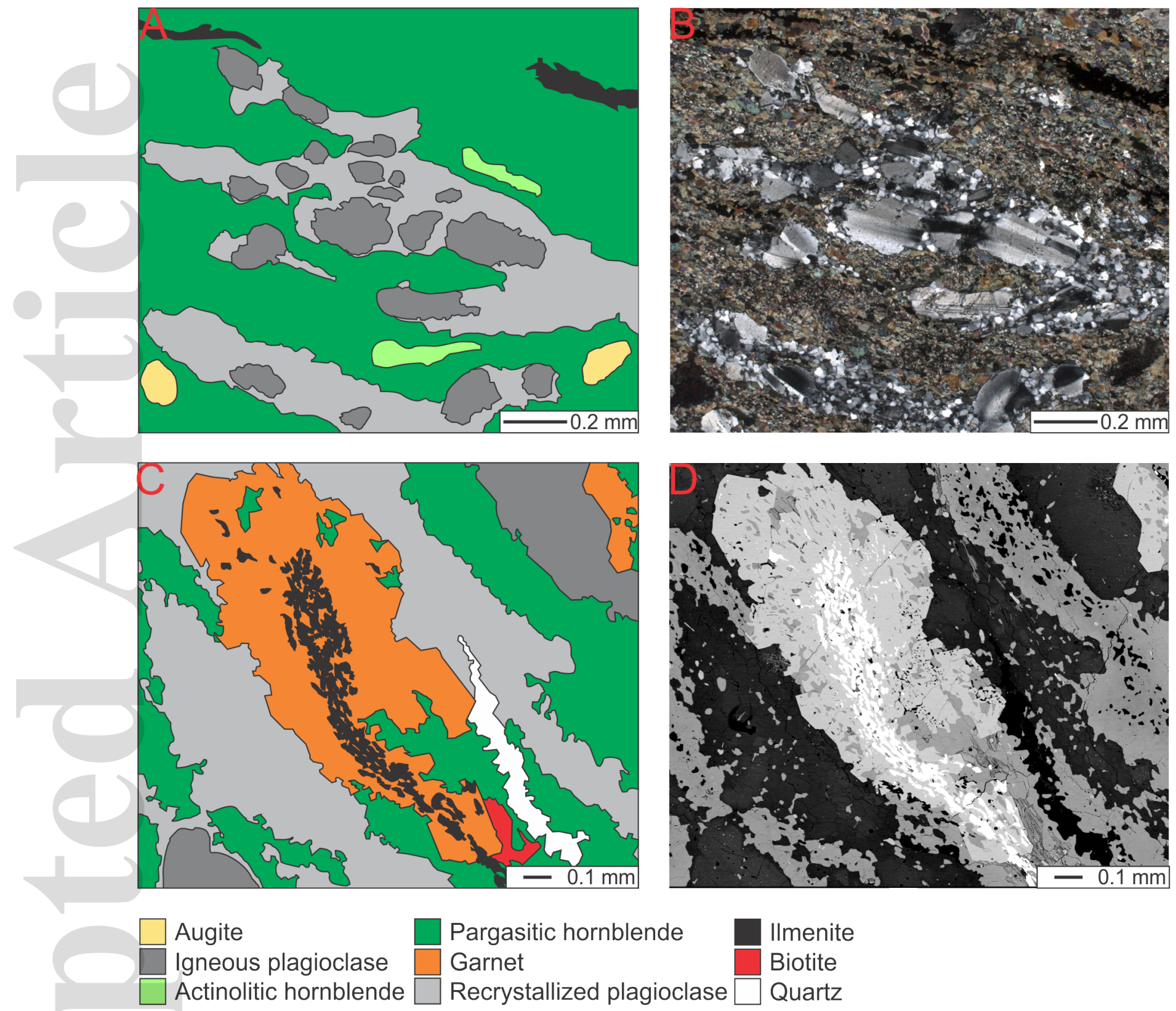

jmg_12582_f6.tif 

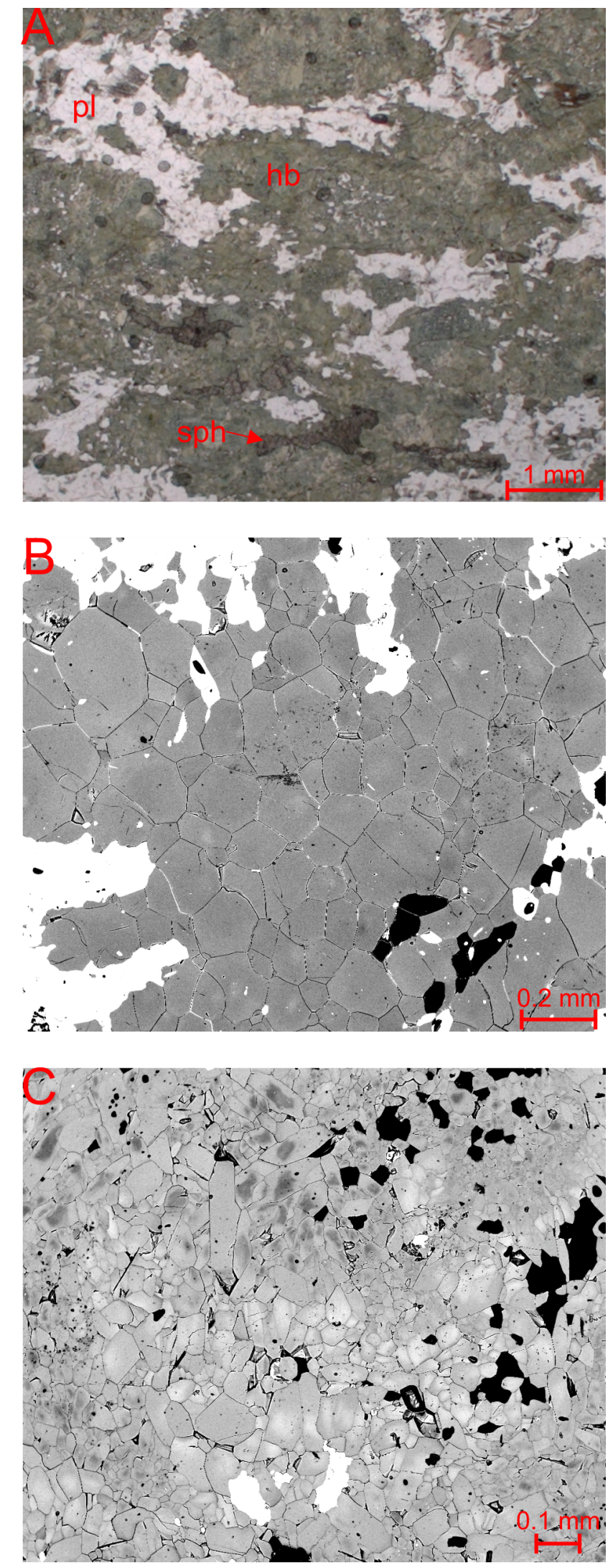

jmg_12582_f7.tif 

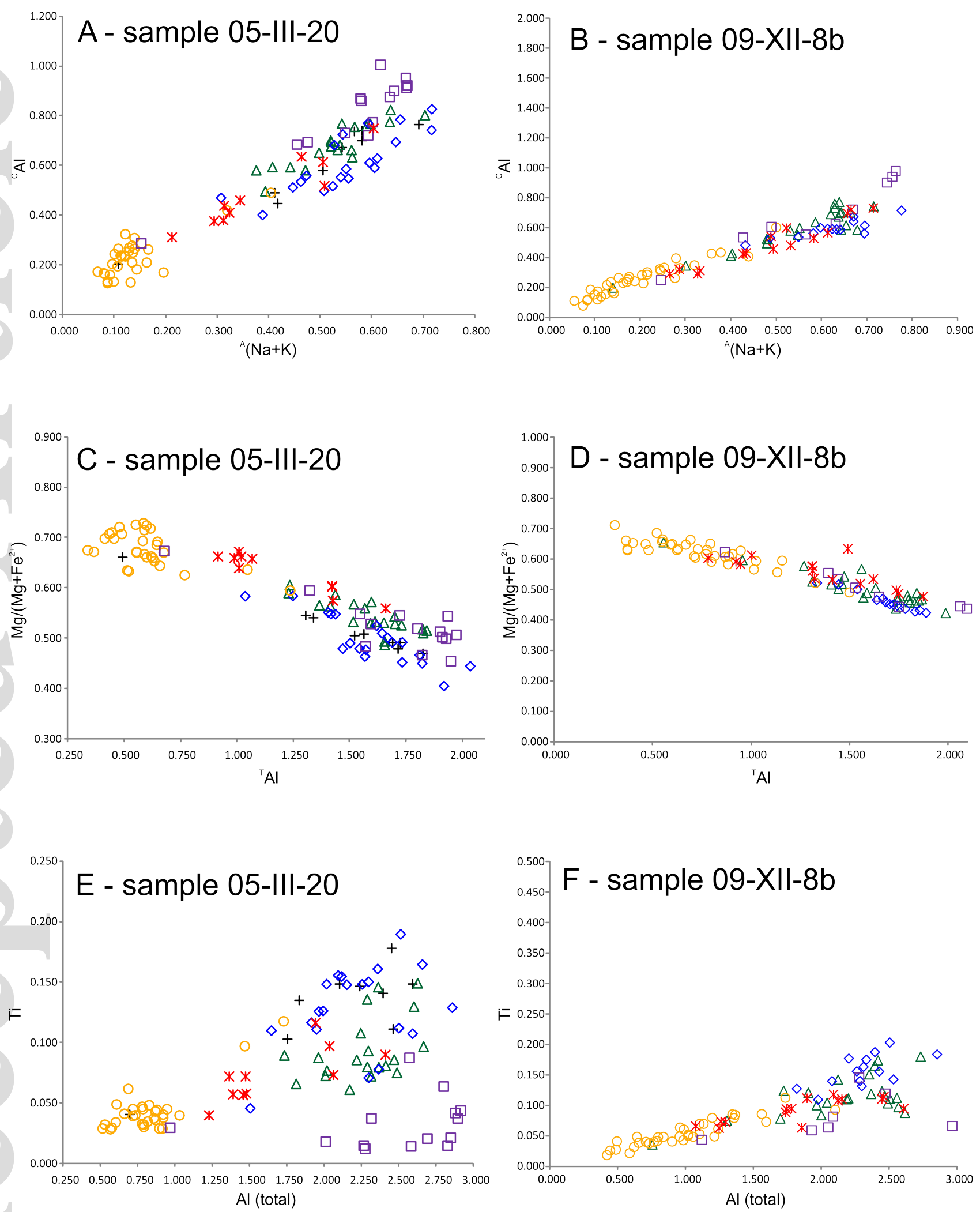

Hornblende types

Pseudomorphs after clinopiroxene $\diamond$ Intergrown with garnet $\triangle$ Mantles around pseudomorphs

* Mantles in contact with clinopyroxene $\square$ Interstices between plagioclase crystals + Mantles around ilmenite

jmg_12582_f8.tif

This article is protected by copyright. All rights reserved 

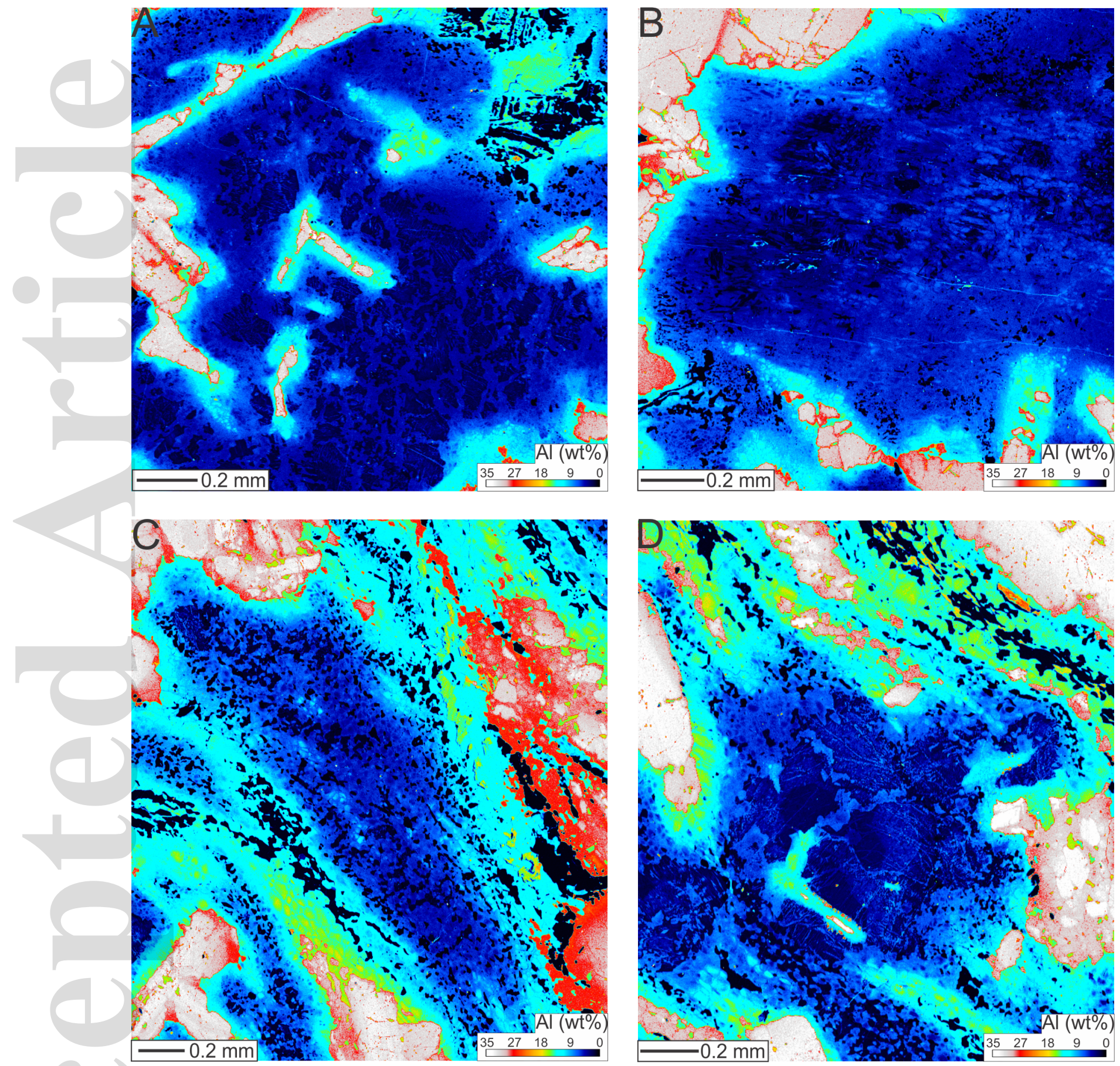

jmg_12582_f9.tif

This article is protected by copyright. All rights reserved 

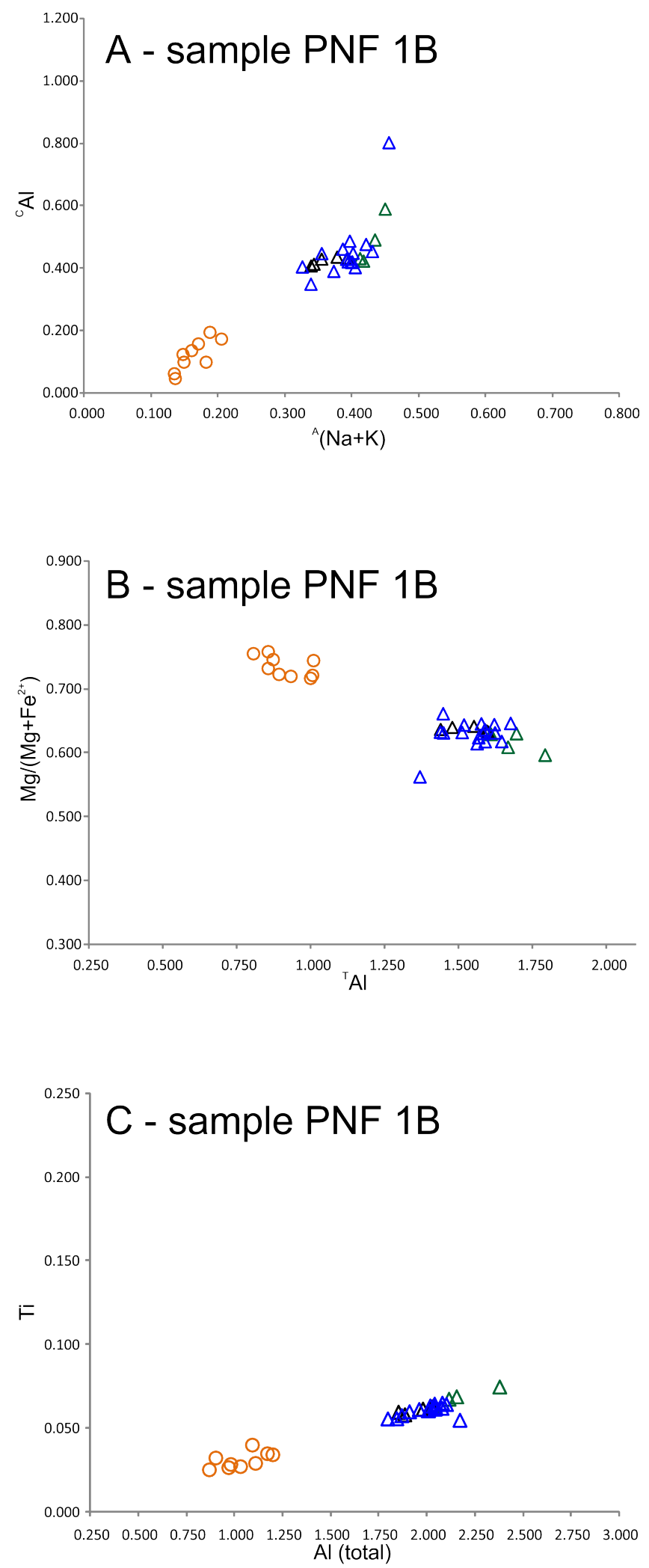

Hornblende types

$\triangle$ Pseudomorph after clinopyroxene $\Delta$ Polygonal: rims and o Polygonal: dark cores unzoned crystals $\triangle$ Polygonal: brigth cores

jmg_12582_f10.tif

This article is protected by copyright. All rights reserved 


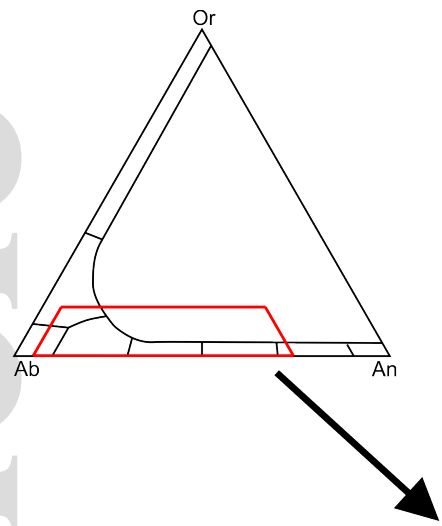

Metagabbro and lineated metagabbro: tabular crystals

$\bigcirc$ Cores $\bigcirc$ Rims
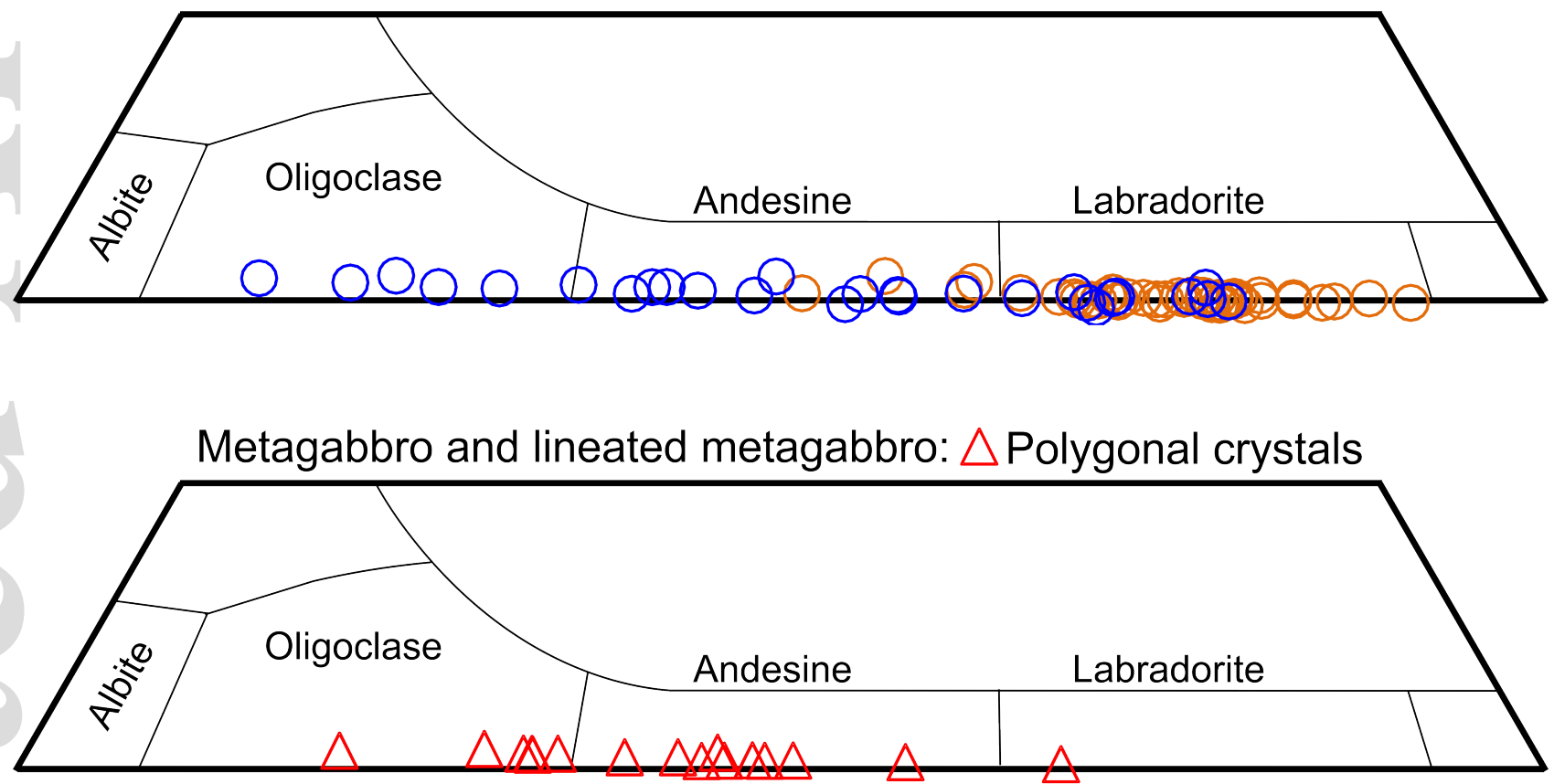

Amphibolite: $\bigcirc$ Tabular crystals-cores; $\bigcirc$ Tabular crystals-rims $\triangle$ Polygonal crystals

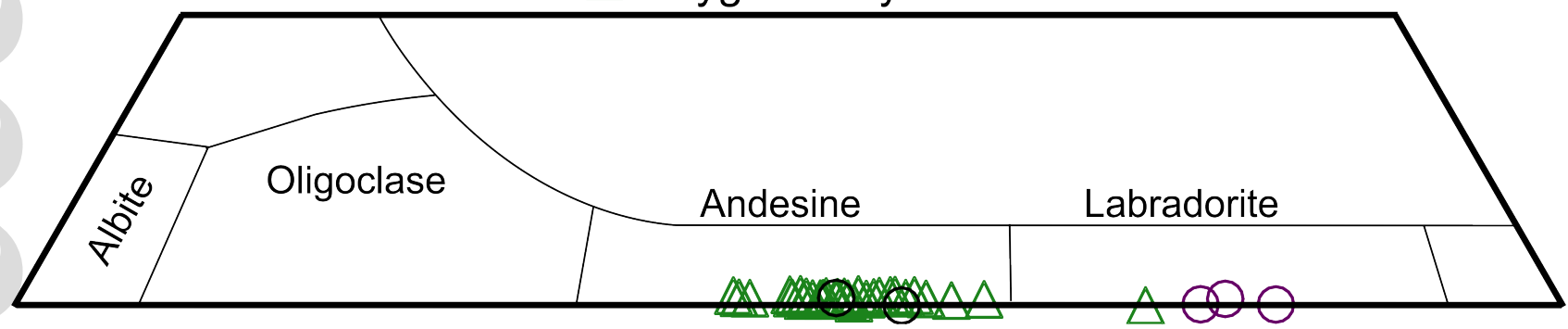

jmg_12582_f11.tif 

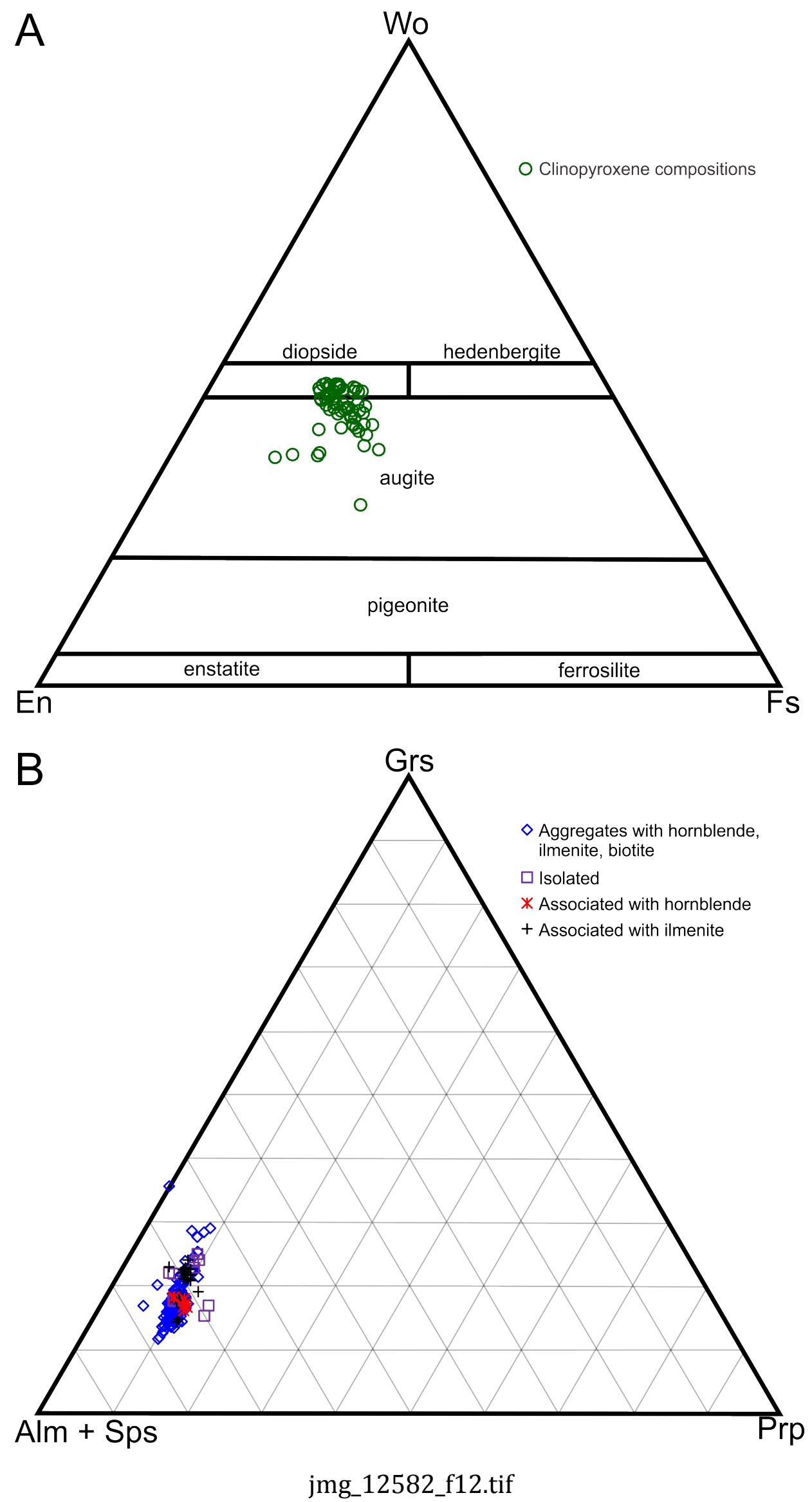

This article is protected by copyright. All rights reserved 

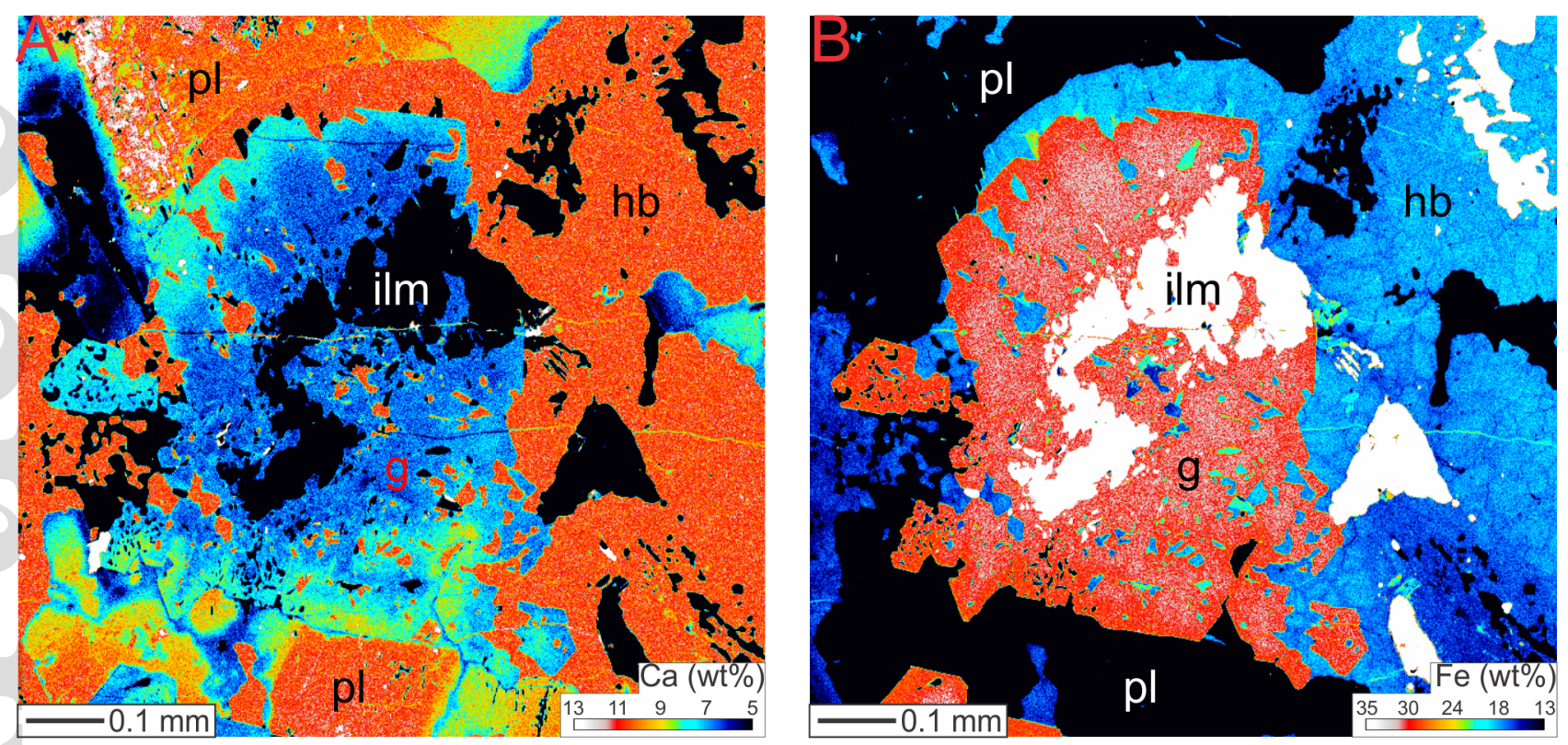

jmg_12582_f13.tif

This article is protected by copyright. All rights reserved 


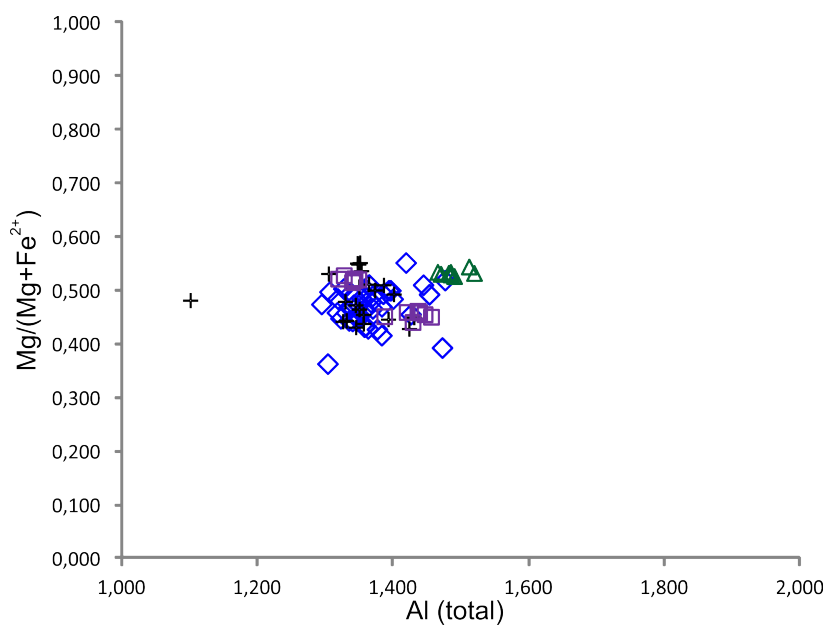

Biotite types

$\diamond$ Metagabbro: associated with $\mathrm{g}, \mathrm{hb}$, ilm

+ Metagabbro: mantles around ilm $\triangle$ Amphibolite

$\square$ Metagabbro: isolated

jmg_12582_f14.tif 

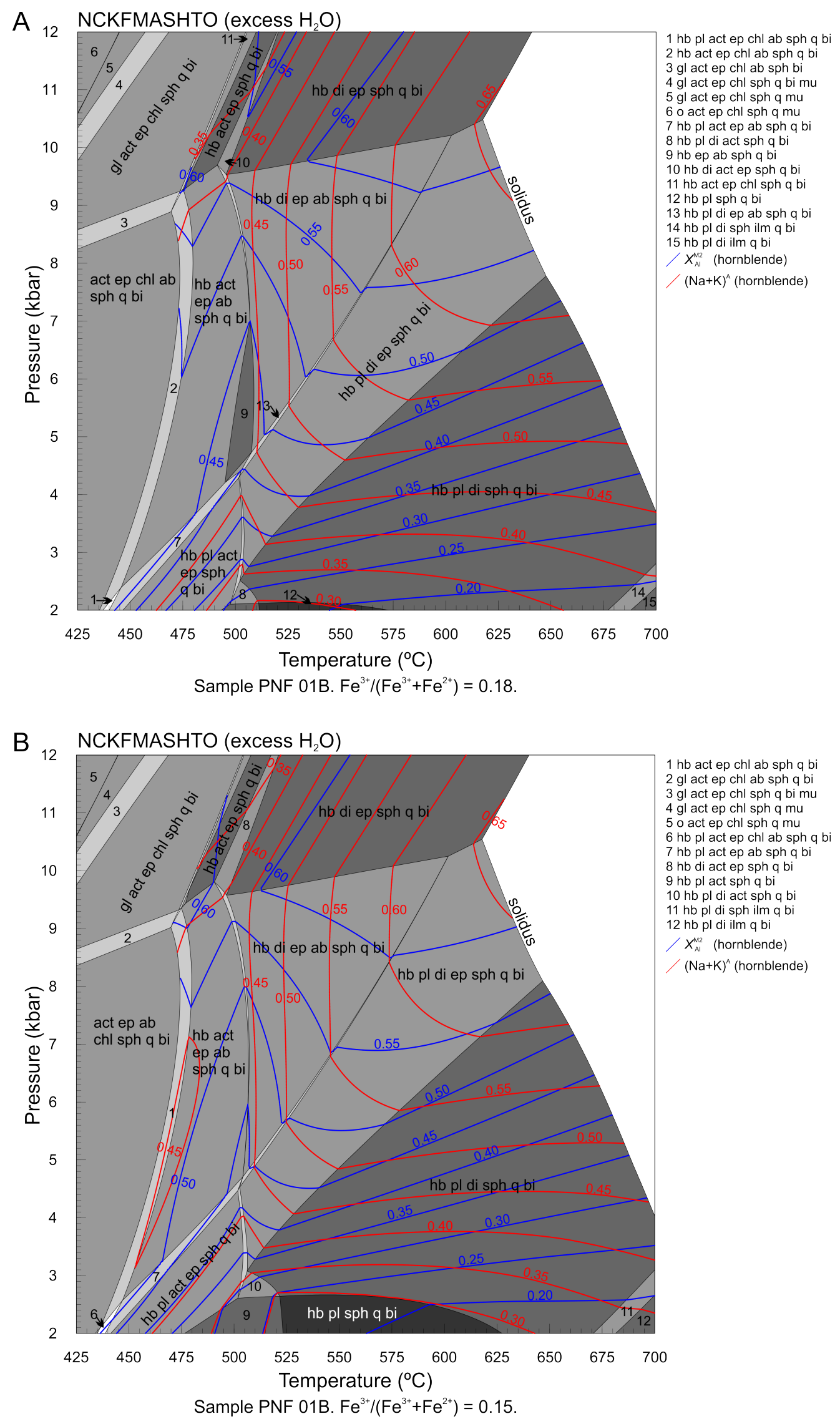

jmg_12582_f15.tif 

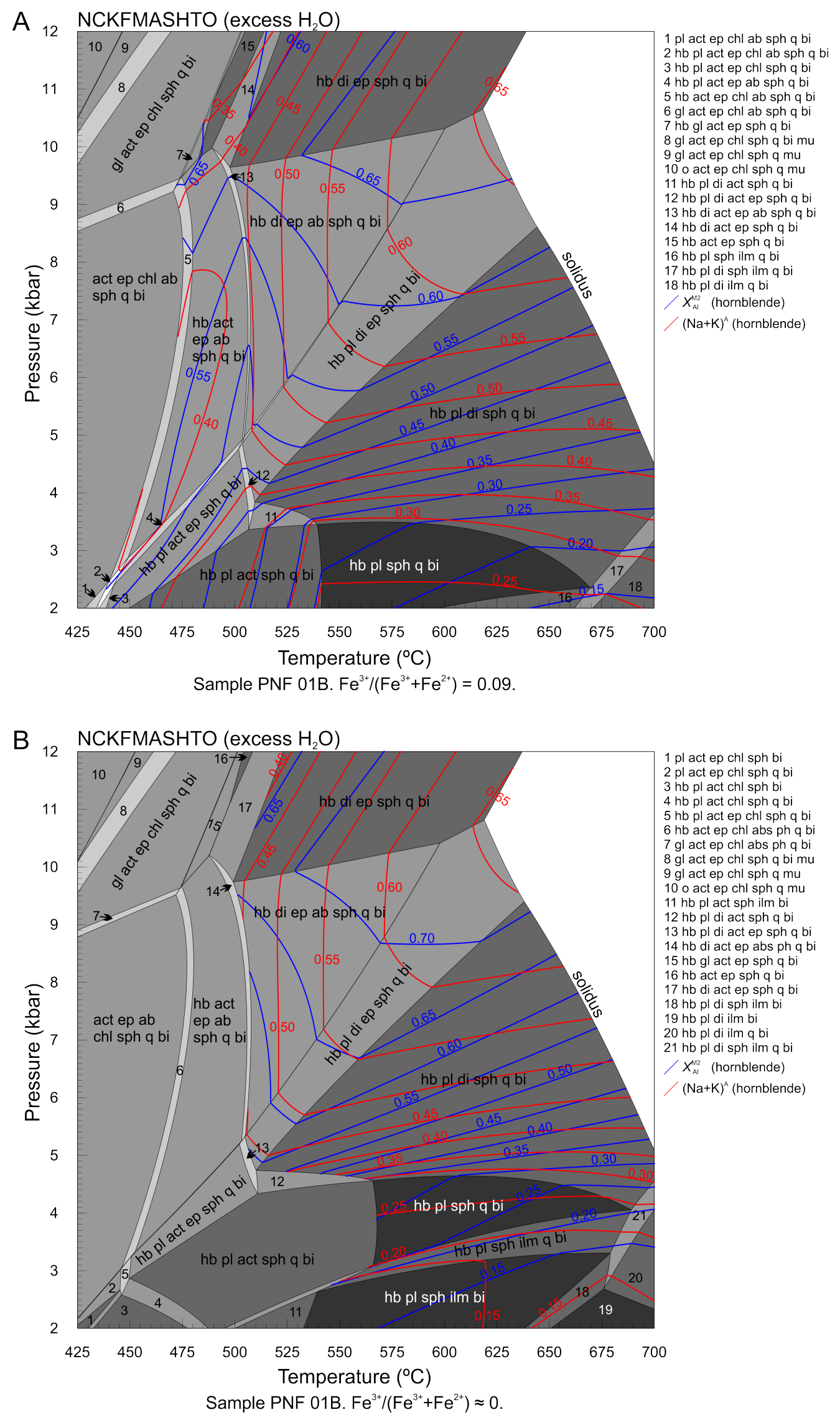

jmg_12582_f16.tif 

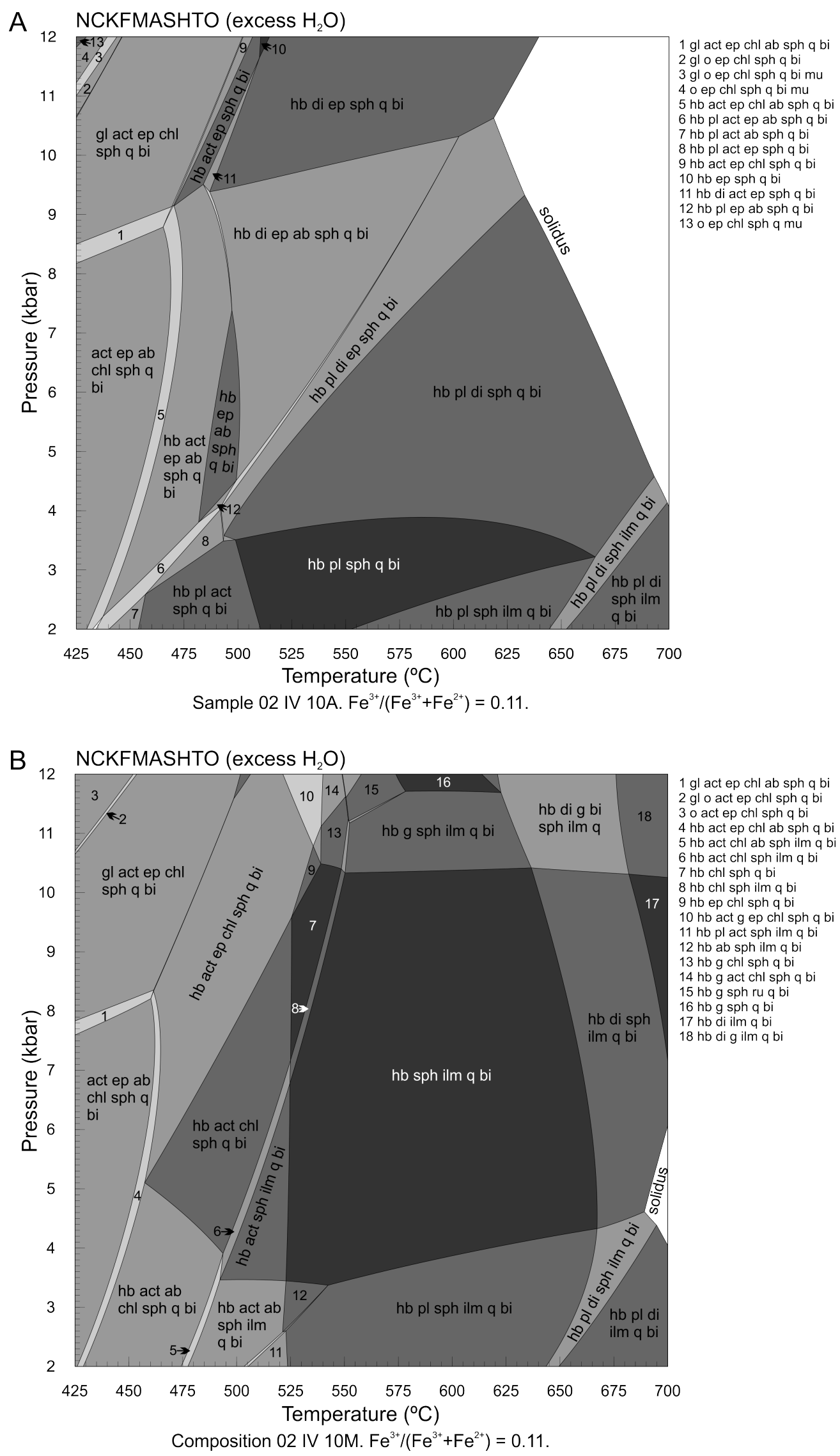

jmg_12582_f17.tif 

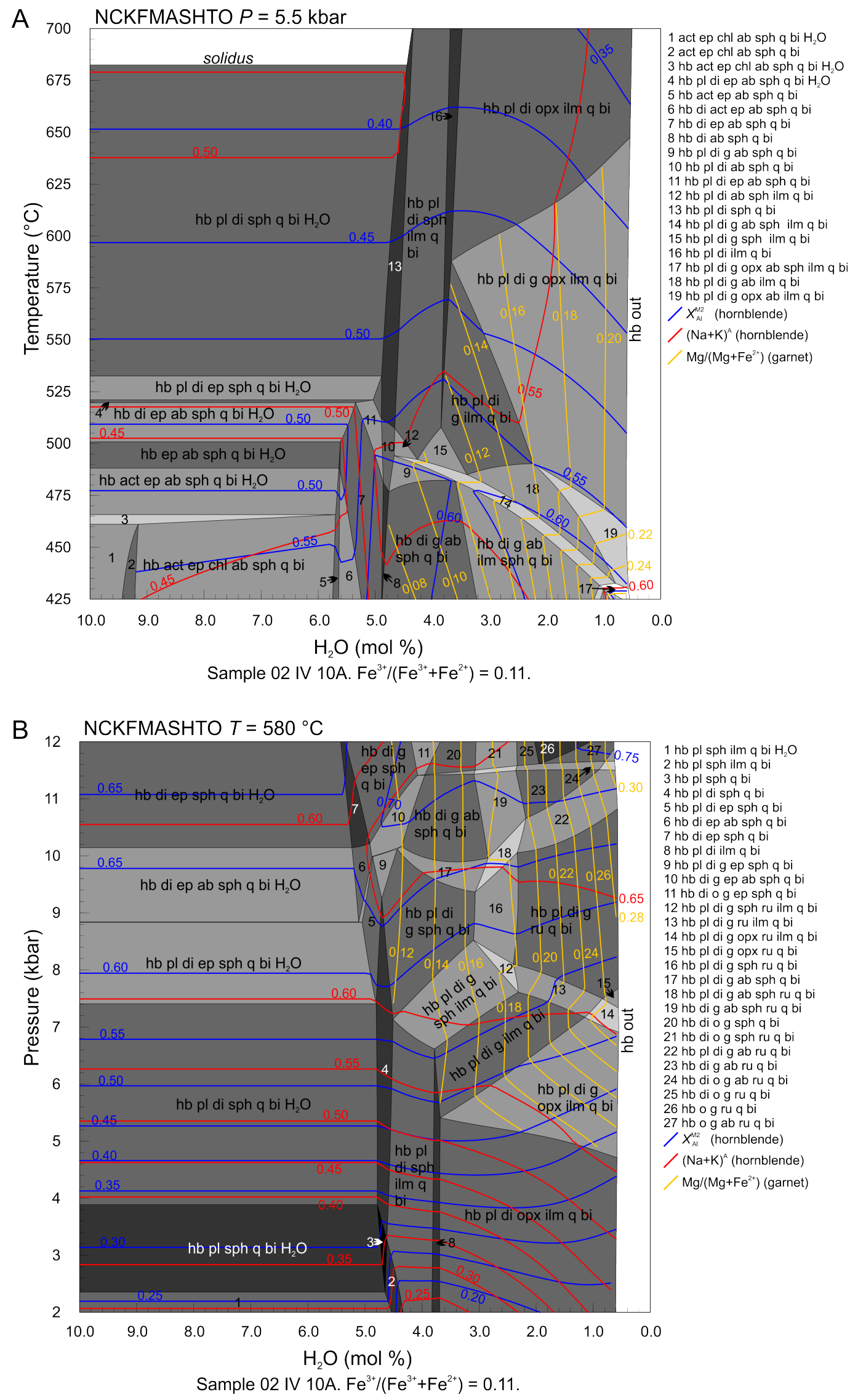

jmg_12582_f18.tif 


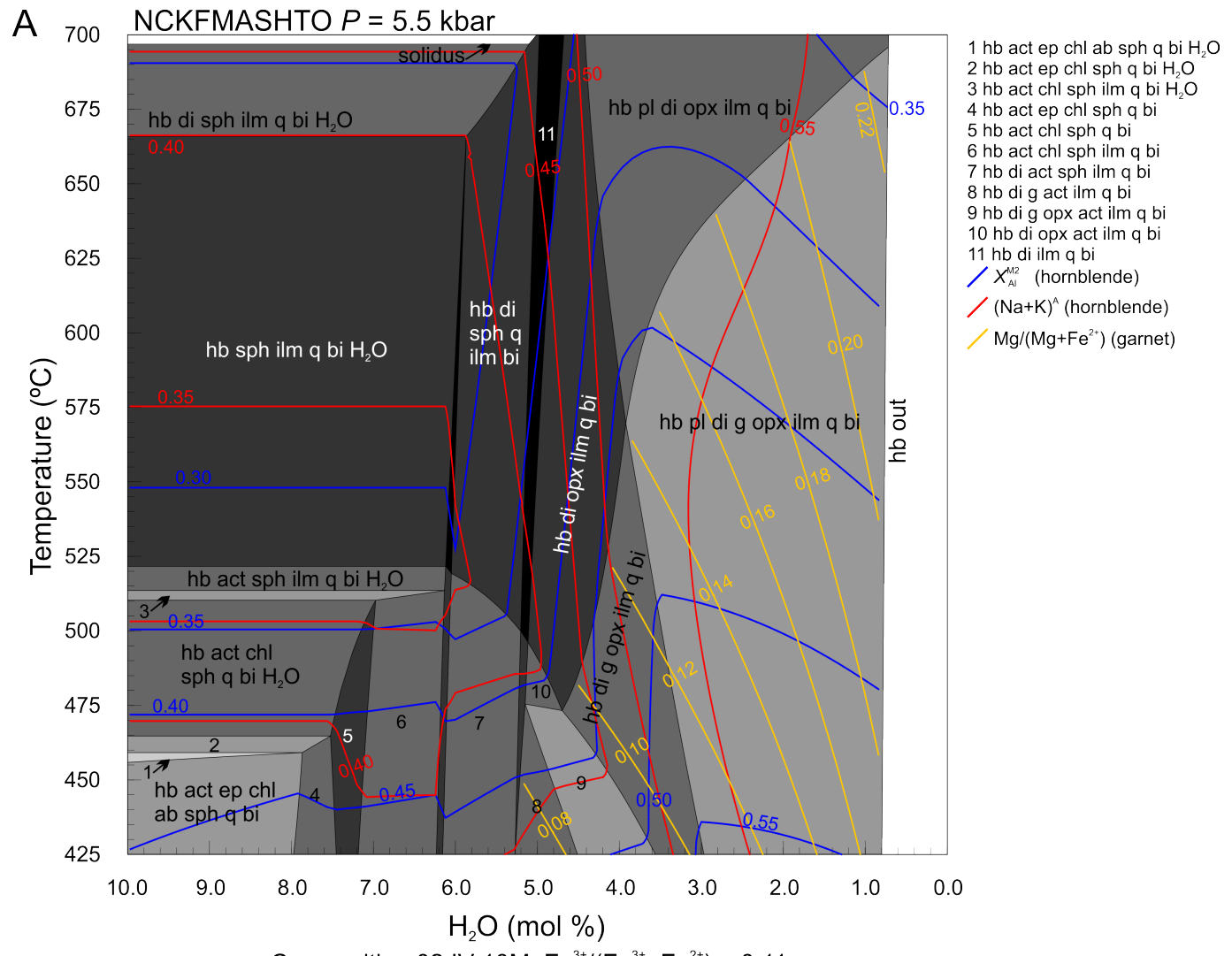

Composition 02 IV 10M. $\mathrm{Fe}^{3+} /\left(\mathrm{Fe}^{3+}+\mathrm{Fe}^{2+}\right)=0.11$

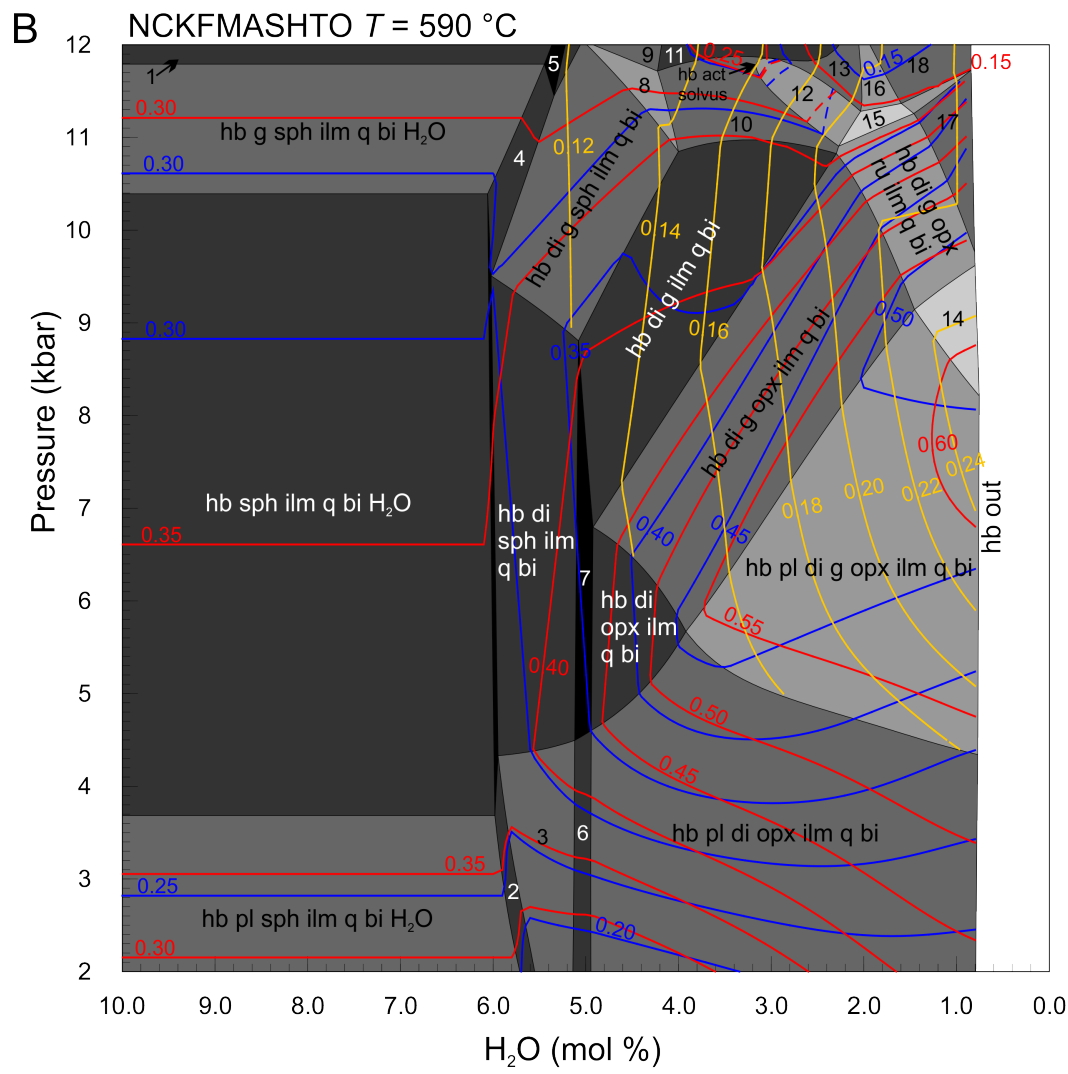

$1 \mathrm{hb} \mathrm{g} \mathrm{sph} \mathrm{q} \mathrm{bi} \mathrm{H}_{2} \mathrm{O}$

$2 \mathrm{hb}$ pl sph ilm q bi

$3 \mathrm{hb}$ pl di sph ilm q bi

$4 \mathrm{hb} \mathrm{g} \mathrm{sph} \mathrm{ilm} \mathrm{q} \mathrm{bi}$

$5 \mathrm{hb} \mathrm{g} \mathrm{sph} \mathrm{q} \mathrm{bi}$

$6 \mathrm{hb}$ pl di ilm q

$7 \mathrm{hb}$ di ilm q bi

$8 \mathrm{hb}$ di g sph ru ilm q bi

9 hb di g sph ru q bi

$10 \mathrm{hb}$ di g ru ilm q bi

$12 \mathrm{hb}$ di $\mathrm{g}$ act ru ilm $\mathrm{q}$ bi

13 di $g$ act ru ilm $q$ bi

$14 \mathrm{hb}$ pl di g opx ru ilm q bi

$15 \mathrm{hb}$ di g opx act ru ilm q bi

16 di g opx act ru ilm q bi

$17 \mathrm{hb}$ di g opx ru q bi

18 di g opx act ru $\mathrm{q}$ bi

$/ X_{\mathrm{Al}}^{\mathrm{M} 2}$ (amphibole)

$/(\mathrm{Na}+\mathrm{K})^{\mathrm{A}}$ (amphibole)

$\mathrm{Mg} /\left(\mathrm{Mg}+\mathrm{Fe}^{2+}\right)$ (garnet)

Composition $02 \mathrm{IV} 10 \mathrm{M}$. $\mathrm{Fe}^{3+} /\left(\mathrm{Fe}^{3+}+\mathrm{Fe}^{2+}\right)=0.11$

jmg_12582_f19.tif 


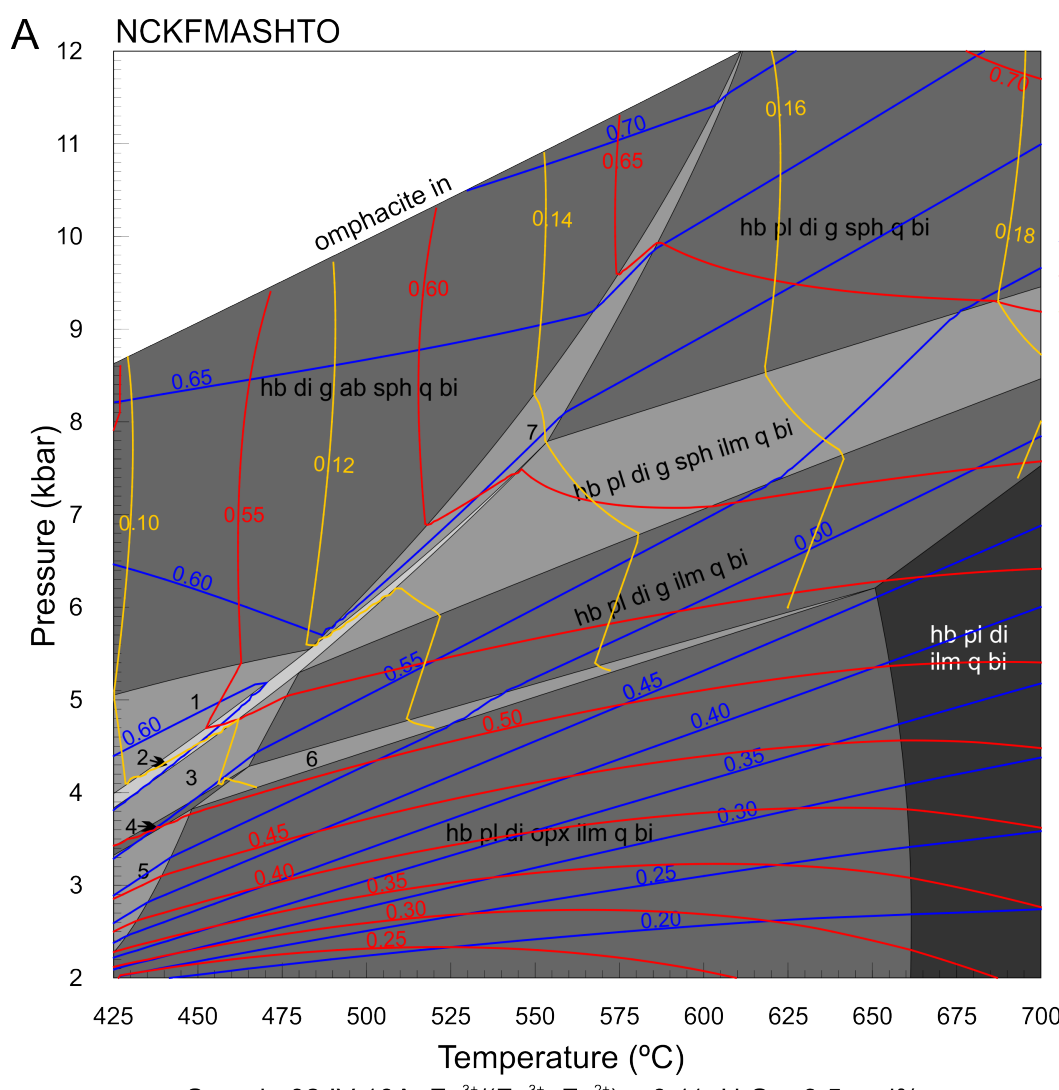

hb di g ab sph ilm q bi $2 \mathrm{hb}$ pl di g ab sph ilm q bi $3 \mathrm{hb}$ pl di g ab ilm q bi $4 \mathrm{hb}$ pl di g opx ab ilm q bi $5 \mathrm{hb}$ pl di opx ab ilm q bi $6 \mathrm{hb}$ pl di g opx ilm q bi 7 hb pl di g ab sph q bi

$/ X_{\mathrm{Al}}^{\mathrm{M} 2}$ (hornblende)

$/(\mathrm{Na}+\mathrm{K})^{\mathrm{A}}$ (hornblende)

$\mathrm{Mg} /\left(\mathrm{Mg}+\mathrm{Fe}^{2+}\right)$ (garnet)

Sample $02 \mathrm{IV} 10 \mathrm{~A}$. $\mathrm{Fe}^{3+} /\left(\mathrm{Fe}^{3+}+\mathrm{Fe}^{2+}\right)=0.11 . \mathrm{H}_{2} \mathrm{O}=3.5 \mathrm{~mol} \%$

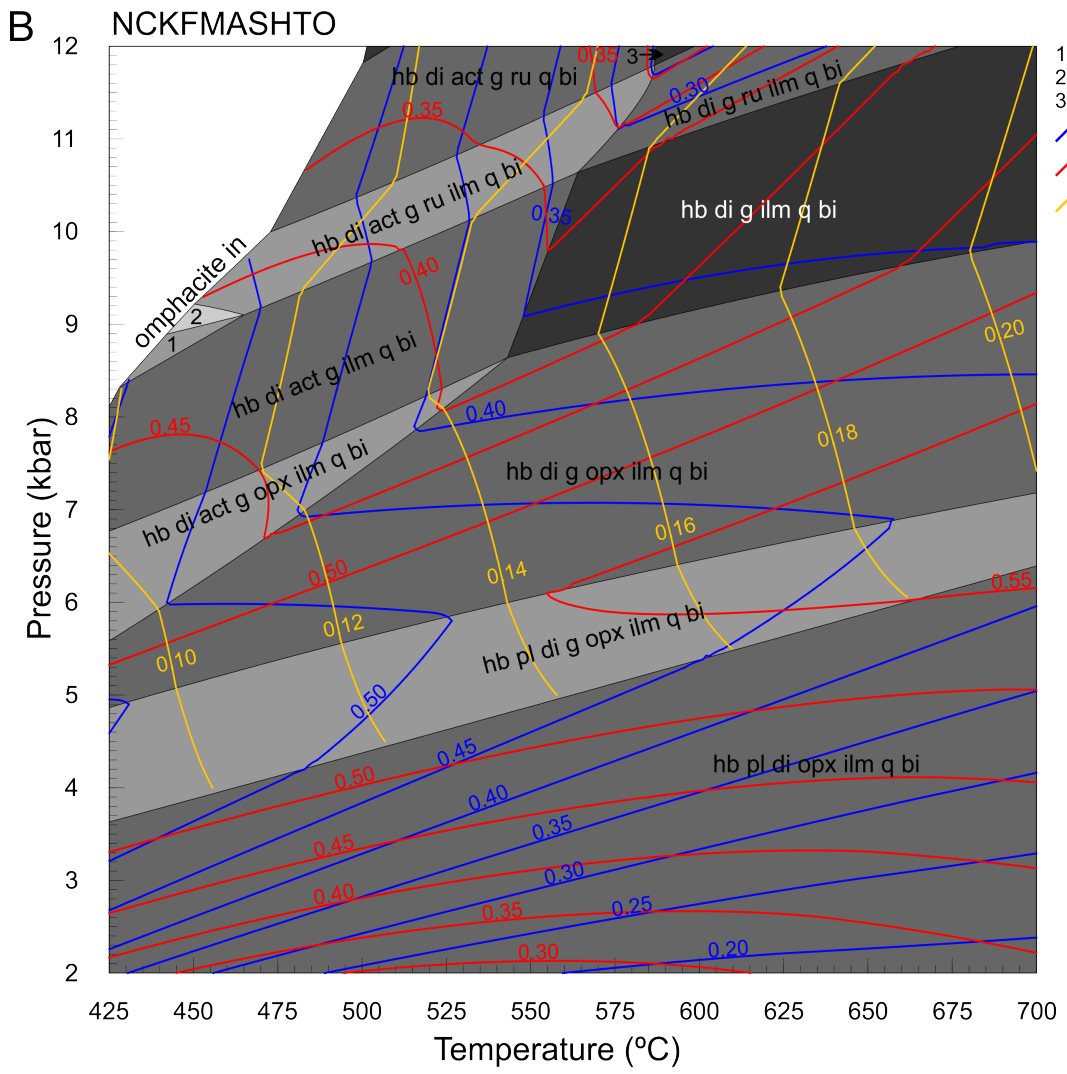

$1 \mathrm{hb}$ di act g sph ilm q bi $2 \mathrm{hb}$ di act $\mathrm{g}$ sph ru ilm $\mathrm{q} b$

$3 \mathrm{hb}$ di g ru q bi

$/ X_{\mathrm{Al}}^{\mathrm{M} 2}$ (hornblende)

$/(\mathrm{Na}+\mathrm{K})^{\mathrm{A}}$ (hornblende)

$\mathrm{Mg} /\left(\mathrm{Mg}+\mathrm{Fe}^{2+}\right)$ (garnet)

Composition 02 IV 10M. $\mathrm{Fe}^{3+} /\left(\mathrm{Fe}^{3+}+\mathrm{Fe}^{2+}\right)=0.11 . \mathrm{H}_{2} \mathrm{O}=3.5 \mathrm{~mol} \%$

jmg_12582_f20.tif 